INNOVATION MOTIVES IN FAMILY FIRMS:

A TRANSGENERATIONAL VIEW

\author{
Vanessa Diaz-Moriana \\ (corresponding author) \\ University of the Balearic Islands (UIB) \\ +34971259620/vanessa.diaz@uib.es \\ Eric Clinton \\ Dublin City University \\ +35317005747/ eric.clinton@dcu.ie \\ Nadine Kammerlander \\ WHU - Otto Beisheim School of Management \\ +49-(0)261-6509-780/ nadine.kammerlander@ whu.edu \\ G. T. Lumpkin \\ University of Oklahoma \\ (405) 325-0716/ lumpkin@ ou.edu \\ Justin B. Craig \\ Kellogg School of Management \\ Northwestern University \\ (847) 467-1082/ justin.craig@ kellogg.northwestern.edu
}

We gratefully acknowledge helpful comments from earlier versions of this manuscript by Dawn DeTienne, David Collings, Colm O'Gorman, Carole Howorth, Maura McAdam, and research seminar participants at DCU Business School (Ireland) and at the University of the Balearic Islands (Spain). We are also grateful for comments from participants at the 2016 Academy of Management Meeting in Anaheim (USA) and the Entrepreneurship and Family Business workshop at Audencia Business School (France). An earlier version of this paper received the Best Paper Award from the 2015 Irish Academy of Management. The first author's work on this paper was partly funded by a research award from the Family Owned Business Institute (FOBI) at Grand Valley State University. This paper builds on material from the first author's dissertation. 


\title{
INNOVATION MOTIVES IN FAMILY FIRMS: \\ A TRANSGENERATIONAL VIEW
}

\begin{abstract}
Drawing on the transgenerational entrepreneurship perspective, we employ a multiple case study approach to investigate why multi-generational family firms innovate. The data collection process drew upon five in-depth cases comprising 42 semi-structured interviews, 25 participant observations, and several thousand pages of historical data dating from 19162017. We find patterns on how the firms' long-term view-embracing both the past and the future-influences the innovation motives of these firms. Specifically, we identify three innovation patterns: conserving, persisting and legacy-building. We introduce a set of propositions and a framework linking long-term orientation dimensions to innovation motives and innovation outcomes. Our research thus contributes to a more fine-grained understanding of innovation behavior in family firms.
\end{abstract}

\section{Introduction}

Innovation is a crucial factor in the long-term survival of any firm (Hult, Hurley \& Knight, 2004). Innovation is particularly important for family firms, as it increases the likelihood of survival across generations (Jaskiewicz, Combs, \& Rau, 2015; Zellweger, Nason, \& Nordqvist, 2011). Family firm survival requires firms to build capabilities such as innovativeness that enable them to respond to changing business and family-related demands, ensuring the firm's continuity (Craig \& Dibrell, 2006). Prior research has concluded that there are mixed findings regarding the relationship between family involvement and innovation (De Massis, Frattini, \& Lichtenthaler, 2013), with some studies suggesting that family firms are particularly innovative (e.g., Kotlar, De Massis, Frattini, Bianchi, \& Fang, 2013; Koenig, Kammerlander, \& Enders, 2013) and others suggesting that family firms are less innovative (e.g., Block, Miller, Jaskiewicz, \& Spiegel, 2013; Matzler, Veider, Hautz, \& Stadler, 2015). By uncovering the innovation activities of family firms (De Massis et al., 2013) and considering specific characteristics that differentiate them from non-family firms (Duran, Kammerlander, van Essen, \& Zellweger, 2016), researchers can gain a more nuanced understanding of family firm innovation and, ultimately, survival.

Interestingly, innovation has been associated with stronger performance outcomes in family firms when driven by long-term perspectives (Kellermanns, Eddleston, Barnett, \& 
Pearson, 2008; McCann, Leon-Guerrero, \& Haley, 2001). Family business literature is strongly influenced by the idea that family firms are heavily oriented towards long-term initiatives (Miller \& Le Breton-Miller, 2005). The long-term approach of some family businesses can result in the formation of special capabilities that allow links to be generated between the past, present, and future (De Massis, Frattini, Kotlar, Petruzzelli, \& Wright, 2016; Zellweger et al., 2011). Moreover, innovation —which is an important source of growth and wealth generation, and is a survival mechanism to protect competitiveness over timehas often been linked to family firms' long-term perspective (Zahra, Hayton, \& Salvato, 2004).

Studies addressing the relationship between innovation and family firms' long-term view, however, have been inconclusive and inconsistent (Carnes \& Ireland, 2013; De Massis et al., 2013). On the one hand, the strong desire to keep the business in the family for generations (e.g., Kellermanns, Eddleston, Sarathy, \& Murphy, 2012; Miller, Le BretonMiller, Lester, \& Cannella, 2007) and to continue the family legacy and decades-old traditions can prevent a family firm from investing in innovative activities that might result in failure or loss of assets. On the other hand, this long-term orientation might foster innovation, as innovation is associated with stronger performance and long-term survival (Cassia, De Massis, \& Pizzurno, 2012; Kraiczy, Hack, \& Kellermanns, 2014; Laforet, 2013). Scholars highlight that the resulting inconsistency affirms the heterogeneous nature of family firms (Chrisman \& Patel, 2012), leading to calls for research to identify the drivers of heterogeneity in family firm innovation (e.g., Craig, Cassar, \& Moores, 2006).

In response, we posit that more in-depth research into family firms' long-term perspective can contribute to a better understanding of family firm innovation. Using insights from the transgenerational entrepreneurship perspective (Nordqvist \& Zellweger, 2010), we suggest that investigating family firms' long-term orientation (Lumpkin \& Brigham, 2011) 
could advance knowledge regarding why multi-generational family businesses innovate and how long-term orientation influences their approach to innovation, if at all. To do so, we draw on an in-depth case study analysis of five innovative and transgenerationally entrepreneurial family firms in Ireland to identify innovation patterns in these firms. Our analysis reveals that a long-term perspective is a particularly useful approach to understanding the motives of multi-generational family firms to innovate, and specifically how innovation manifests distinctively by context. We present a framework that provides insights into the innovation patterns of multi-generational family firms and extends knowledge on family firm innovation by helping explain their heterogeneous nature.

Our study makes several important contributions. First, we expand current family business innovation literature and provide a more nuanced understanding of why and how multi-generational family firms innovate. Our findings suggest that long-term orientation is particularly important in understanding innovation in family firms. Notably, our empirical results serve as initial evidence that specific innovation motives in family firms are associated with different aspects of long-term orientation, and consequently influence the firms' innovative outcomes. Accordingly, one of this study's key contributions is the proposition that a long-term perspective is not only compatible with innovation but that it may also be an important shaper of specific innovative behavior in multi-generational family firms. This is important because prior family firm literature has largely treated innovation as a homogeneous phenomenon (Subramaniam \& Youndt, 2005) despite ample evidence that the innovation patterns of family firms differ between firms (Damanpour, 1991). Second, we emphasize the importance of treating family firms as heterogeneous (e.g., Chua, Chrisman, Steier, \& Rau, 2012; Li \& Daspit, 2016) by integrating a construct-long-term orientation (LTO) - that illuminates our understanding of different approaches to innovation behavior by family firms. Recent research exploring innovative family firms suggests that the family's 
rhetorical reconstruction of past entrepreneurial achievements or resilience can motivate subsequent generations to engage in innovative activities, thus fostering transgenerational entrepreneurship (Jaskiewicz et al., 2015). We suggest that family firms' long-term orientation has consistent patterns associated with their innovation motives which impact innovation behavior in subsequent generations, thereby nurturing transgenerational entrepreneurship. Finally, we contribute to the family business literature in general, as we apply a temporal construct-LTO - and integrate it with the transgenerational entrepreneurship perspective. In doing so, we extend the application of temporal constructs in family business research, which to date have largely been ignored (Sharma, Salvato, \& Reay, 2014). Furthermore, our study examines LTO as a multidimensional construct; it has usually been treated as a unidimensional construct, neglecting the effects of its individual dimensions. Applying a transgenerational entrepreneurship lens, we develop a set of propositions and a framework which provide insight into the innovation patterns that multi-generational family firms employ.

\section{Theoretical Background}

\section{Innovation and Transgenerational Entrepreneurship in Family Firms}

Since the seminal work of Schumpeter (1934), scholars have considered innovation a critical determinant of a firm's long-term success. Innovative activities are considered vital for a firm's survival (Van Gils, Dibrell, Neubaum, \& Craig, 2014; Wiklund \& Shepherd, 2005), competitive advantage (Greve, 2009; Slevin \& Covin, 1995), and performance (Blundell, Griffiths, \& Van Reenen, 1999; Tsai \& Yang, 2012). Innovation is concerned with generating, adopting, and implementing new ideas, processes, products, or services (Thompson, 1965). While innovation can take many forms, it is the component of novelty and newness that distinguishes it (Johannessen, Olsen, \& Lumpkin, 2001). Thus, along with activities typically associated with innovation—such as research and development and 
technological breakthroughs_-are advances in marketing, new product development, supply chain management, manufacturing processes, organizational structuring, and human resource management (Cassia et al., 2012; Craig \& Dibrell, 2006; Kammerlander, Dessi, Bird, Floris, \& Murru, 2015). Innovation can also lead to unfamiliar or less frequent scenarios such as acquiring an innovative new firm or embracing new routines that disrupt the status quo (Bessant, Lamming, Noke, \& Phillips, 2005; Nohria \& Gulati, 1996). In today’s complex environment, firms need to adapt to changes, and innovation has been acknowledged as one of the most important competitive advantages for firms (Damanpour, 1991).

In the context of family firms, innovation is particularly important as it increases the likelihood of survival across generations (Jaskiewicz et al., 2015; Zellweger et al., 2011) consistent with those firms' vision for continuity and transgenerational succession (Chua, Chrisman, \& Sharma, 1999). Family firm survival requires firms to build capabilities that ensure their responsiveness to changing business and family-related demands for the continuity of the firm (Craig \& Dibrell, 2006). As a consequence, they likely support innovation as a source of firm growth and survival (Zahra et al., 2004). Although innovation in family business as a research field is gaining increased momentum (see review by Rod, 2016), inconclusive and inconsistent findings have emerged (Carnes \& Ireland, 2013; De Massis et al., 2013; Duran et al., 2016; Filser, De Massis, Gast, Kraus, \& Niemand, 2017). On the one hand, the capital constraints imposed by family ownership structures (Carney, 2005) and the concentration of decision-making authority (Damanpour, 1991) might prevent them from investing in innovative activities. Furthermore, family firms also take non-economic factors into consideration when deciding how to invest their funds (Astrachan \& Jaskiewicz, 2008; Chua et al., 2003; Kammerlander \& Ganter, 2015; Matzler et al., 2015) which can prevent a family firm from investing in high-risk innovative activities (Naldi, Nordqvist, Sjoberg, \& Wilklund, 2007) in order to safeguard the business for future generations (e.g., 
Kellermanns et al., 2012; Miller et al., 2007). On the other hand, many family firms possess decision-making capabilities, power, and flexibility that enable them to undertake innovative initiatives (Miller \& Le-Breton Miller, 2005). Family firms' characteristics, such as low levels of bureaucracy (Kets de Vries, 1993), flexibility of organizational structures (Craig, Dibrell, \& Davis, 2008), perceived organizational support (Bammens, Notelaers, \& Van Gils, 2015) and loyal employees (Duran et al., 2016), have been shown to promote innovative activity. Reconciling some of those ambiguities, recent research proposes that family firms are faced with an ability-willingness paradox with regards to innovation (Chrisman, Chua, De Massis, Frattini, \& Wright, 2015; De Massis, Kotlar, Chua, \& Chrisman, 2014). These studies argue that family firms have a greater ability (discretion to act) to engage in innovation activities but lower willingness (disposition to act) to do so when compared to non-family firms.

Review articles on innovation in family firms highlight that in order to understand family firm innovation, it is necessary to uncover the innovation activities of family firms (De Massis et al., 2013) and to consider specific characteristics that differentiate them from nonfamily firms (Duran et al., 2016). In particular, innovation has been linked to stronger performance outcomes in family firms when driven by strategic decision-making and longterm perspectives (Kellermanns et al., 2008; McCann, Leon-Guerrero, \& Haley, 2001). As mentioned above, innovation is particularly important in family firms as it increases the likelihood of survival across generations (Jaskiewicz et al., 2015) consistent with their vision for continuity and transgenerational succession (Chua et al., 1999). Thus, to explore the innovation motives of family firms across generations we draw on the concept of transgenerational entrepreneurship (Nordqvist \& Zellweger, 2010).

A fundamental principle of transgenerational entrepreneurship is the focus on the family and how the family impacts the entrepreneurial activity and longevity of the firm (Zellweger \& Sieger, 2012). The transgenerational entrepreneurship literature is based on the premise that 
family firms create new streams of value across generations through developing long-term entrepreneurial mindsets - the attitudes, values, and beliefs that direct individuals to pursue entrepreneurial activities (Lumpkin \& Dess, 1996). Researchers have explored a range of possible determinants of successful transgenerational entrepreneurship such as entrepreneurial orientation (Nordqvist, Habbershon, \& Melin, 2008), organizational culture (Zahra et al., 2004), familiness (Zellweger, Eddleston, \& Kellermanns, 2010), family's financial and social capital (Aldrich, Renzulli, \& Langton, 1998), stewardship perspective (Eddleston, Kellermanns, \& Zellweger, 2012), or entrepreneurial legacy (Jaskiewicz et al., 2015). Entrepreneurship is also fostered through family firms that promote participative decisionmaking (Kellermanns \& Eddleston, 2006) and a long-term vision (Lumpkin, Brigham, \& Moss, 2010). In this sense, the transgenerational entrepreneurship view adopts a long-term view by focusing on how value is created not only for the incumbent but also for future family generations (Habbershon \& Pistrui, 2002; Zellweger et al., 2011).

\section{Long-Term Perspective}

A long-term perspective has been introduced as a way to capture the potential advantages and benefits enjoyed by families in business as a result of how they perceive time (Miller \& Le-Breton Miller, 2005). This approach is consistent with other family business research, such as works on 'familiness' (Habbershon, Williams, \& MacMillan, 2003) and 'particularistic behavior' (e.g., Carney, 2005) that identifies idiosyncratic attributes—such as the long-term orientation of family firms (Drakopoulou Dodd, Anderson, \& Jack, 2013) which are unique to family firms and help explain their strategic behavior. Time-sensitive decisions are especially relevant to multi-generational family firms (Anderson \& Reeb, 2003) due to, for example, their interest in legacy and lasting values (Ward, 2004), and their capacity to build enduring relationships (Arregle, Hitt, Sirmon, \& Very, 2007). Embedded in the organizational mind-set of the firm, LTO refers to "the tendency to prioritize the long- 
range implications and impact of decisions and actions that come to fruition after an extended time period" (Lumpkin et al., 2010, p. 241); a dominant logic that prioritizes long-range implications and determines organizational actions (Le Breton-Miller \& Miller, 2011). Although some family firms will prioritize the long-term more than others, it is generally agreed that family businesses are more likely to be long-term oriented than non-family firms (Gomez-Mejia, Haynes, Núñez-Nickel, Jacobson, \& Moyano-Fuentes, 2007; Kellermanns et al., 2008).

Researchers have emphasized the importance of a long-term perspective in family firms exercising strategic behavior. For instance, in a sample of 409 US manufacturing firms, Zahra (2003) found that family governance had a positive effect on internationalization activities. This was attributed to the altruistic behavior of family business leaders towards future generations, which, in turn, promotes risk-taking and long-term orientation. Zellweger (2007) argued that firms with long-range perspectives (e.g., family firms) invest in less risky projects more so than firms with short-range perspectives, and also create equal shareholder value. Family firms often invest in projects with returns deemed insufficiently attractive by nonfamily firms, which provides an opportunity to acquire markets unoccupied by these counterparts. Similarly, Villalonga and Amit (2010) found that family firms are less sensitive to profit shocks due to their long-term commitment approach. This is consistent with the findings of Andres (2011) who found that family firms are less sensitive to the availability of internal cash flow and more responsive to investment opportunities due to the lower agency cost and long-term view.

While these studies acknowledge the advantages of a family firm's long-term perspective and the importance of innovation for their growth and survival, only a few studies have endeavored to link the two perspectives. For instance, there is evidence that executives in family firms with a long-term orientation have an additional incentive to enhance new product 
portfolio performance (Kraiczy et al., 2014). Cassia et al. (2012) found that long-term orientation positively influences new product development (NPD) activities and Laforet (2013) posited that market conditions, industry sector, business goals, and long-term orientation positively affect family firm innovation. Lumpkin and colleagues (2010) contend that a longer time horizon can benefit innovation as it makes the family firm more tolerant to experimentation and prolongs the time for creativity. Successful dynastic families view innovation as a way to continuously search for new technologies and new markets while securing long-term wealth (e.g., Bergfeld \& Weber, 2011). These studies suggest that the long-term orientation of family firms influences the firm's ability to innovate which, in turn, helps these firms to identify opportunities resulting in long-term survivability.

Studies applying the socioemotional wealth (SEW) approach, however, are inconsistent with the accepted premise that family firms have a long-term perspective (e.g., Gómez-Mejía et al., 2007) suggesting that the primary driver of strategic decision-making in family firms is the potential loss of socioemotional wealth, and avoiding risky decisions that might decrease this asset. The most important implication is that family firms are more likely to follow strategies that are control-oriented rather than long-term oriented. In line with this, a study by Chrisman and Patel (2012) proposes that the family firm's tendency to engage in long or short-term investment horizons depends on whether the family aims to preserve SEW in the short-term, or to maintain the longevity of the firm and the transfer of control to subsequent generations. Such perspectives call for more careful attention in untangling why family firms innovate and how temporal perspectives might influence this motivation. In viewing this as a starting point, this paper aims to extend knowledge of family firm innovation by asking whether there is a distinct temporal characteristic of these firms.

We suggest that exploring family firms' long-term perspective in association with innovation may be particularly important to understanding the innovative behavior of these 
firms, because a long-term orientation has been found to be common in family firms (Miller \& Le-Breton Miller, 2005) and to be important for the continuity of the family business (Zellweger et al., 2011) as well as for preserving the entrepreneurial mindset across generations (Jaskiewicz et al., 2015). Our study is primarily concerned with exploring the motives behind family business innovations over time, and whether the innovation patterns that multi-generational family firms exhibit are linked to long-term characteristics. Specifically, we seek to investigate the following research question: "Why do multigenerational family firms innovate and how does long-term orientation influence their approach to innovation, if at all?"

\section{Methodology}

\section{Research Design}

A qualitative research design was deemed particularly appropriate for our research question given our focus on "why" and "how" questions (Yin, 2003). Specifically, we used a multiple case study methodology (De Massis \& Kotlar, 2014; Eisenhardt, 1989; Handler, 1989; Yin, 2009) as it facilitates an in-depth examination of each case and the identification of patterns (or the lack thereof) across cases.

\section{Data Sample}

We followed a purposeful theoretical sampling technique (Merriam, 1998) in which cases were selected based on their probability of providing significant information regarding the phenomenon under investigation (i.e., the innovation patterns). The sample involved five family firms that participated in the Successful Transgenerational Entrepreneurship Practices (STEP) project. STEP is a global research initiative analyzing entrepreneurship in multigenerational family firms. Specifically, it investigates the impact of divergent resources and entrepreneurial attitudes (innovation among them) on financial, entrepreneurial, and social performance outcomes across family firm generations. In order to be included in the STEP 
project family firms must meet the following criteria: (1) The owning family must see their business as a family business; (2) The family must hold majority ownership in the main operating business; (3) There must be at least one active operating business; (4) Generational involvement in ownership and/or management must span at least two generations; (5) The main operating business must employ at least 50 employees; and (6) The owning family must have an ambition to pass on the business to the next generation (Nordqvist \& Zellweger, 2010). We selected firms that differed in age (from 21 to 232 years), size (from 50 to 300 employees), industry (hot beverage drinks, water treatment, food, timber and agricultural machinery), turnover (from $\$ 11 \mathrm{M}$ to $\$ 110 \mathrm{M}$ ), and generation (from second to seventh) in order to enhance diversity. The five firms all shared the same geographic location (Ireland), thus limiting external variation.

\section{Data Collection}

This study employs a combination of primary and secondary data, consisting of initial and follow-up interviews, archival records, and observations gathered over three years.

Interviews. The main data collection consisted of 42 semi-structured in-depth interviews with owners and senior family members active in the business, non-family executives, and board members. Interviews are often the primary data source in case studies (Eisenhardt \& Graebner, 2007). In this study, the interviews included respondents from multiple generations, which is an important methodological aspect when researching family firms (Nordqvist, Hall, \& Melin, 2009). Furthermore, since all the firms participating in STEP must include generational involvement spanning at least two generations and must have an ambition to pass on the business to subsequent generations, data gathering about family firms with a transgenerational perspective was ensured. The interviews were conducted according to the STEP semi-structured interview guidelines. The interview guide, which built on insights from entrepreneurship and family business scholarship (e.g., Habbershon et al., 2003; Lumpkin \& 
Dess, 1996) includes questions regarding historical development and innovation, among others, such as "Describe key innovations, new ventures, new markets or renewal activities that have made a difference in what you are today"; and, "What are the most important entrepreneurial outcomes to the ownership and management of the business or group (i.e. traditional entrepreneurial activities: new products, new businesses, innovations, new business models, change activities)?". We also included additional open-ended questions relating to the firms' history, approach to innovation, motivation for innovation, and continuity of the family firm. The interviews ranged from 35 to 92 minutes and were recorded and transcribed verbatim. This resulted in over 32 hours of interviews captured by 645 pages of interview transcripts.

Observations. After each round of interviews, members of the team took notes to detail participants' observations and feelings. In particular, we included 25 observations involving various interactions with the firms i.e. plant tours and industry conferences at which presentations were made by the family, a centenary celebration, and formal meals with the family members (see Table 1). We observed the behaviors of the senior executives and paid attention to the stakeholder interactions, conversations, and surroundings (Yin, 2003).

To gain additional information and updates on particular topics, multiple follow-up conversations took place with family and non-family stakeholders, which allowed for any clarifications needed when analyzing the data. Once the data were analyzed, we arranged follow-up interviews with the CEOs of the first four cases to resolve any discrepancies and to validate the insights to answer the research questions of this study (Creswell, 2009). In doing so, we verified the accuracy of the case histories by sharing them with our participants. The last case was unable to participate in the follow-up interviews. The supporting interviews ranged from 25 minutes to 40 minutes in length. 
Archival data. Secondary data collection began with a review of the company's website, media articles, documentaries, and videos to gather initial information about the firms' histories and their innovations. Further secondary data was provided by the firms during the interview period such as company reports, company presentations, and company history books. During the data analysis period, researchers also collected further material which included media articles, television and radio documentaries, videos, public professional profiles of interviewees, public corporate pages, and documents with the National Company Register. These archival records (310 pieces of evidence in total) dating from 1916-2017 provided two benefits: firstly, the records allowed the team to trace the family firms over almost a century; and secondly, method triangulation was facilitated (Eisenhardt \& Graebner, 2007). Table 1 provides an overview of the firms involved and the data sources employed.

\section{"Insert Table 1 Here"}

\section{Data Analysis}

Our team included five members who specialize in innovation, entrepreneurship, and strategic management in family business, which aided in the reliability of the coding while also offering divergent perspectives. The steps of analysis were completed independently by two team members, who met periodically to compare their individual interpretations. Initial discrepancies between interpretations were debated with a third team member until consensus was reached. We followed a structured process for data analysis, recommended by Miles and Huberman (1994), which unfolded in several steps beginning with data coding and resulting in the following within-case and cross-case analyses. First, we reviewed all transcripts and secondary data carefully and highlighted quotes that appeared to reflect innovative behavior. We coded the material and created categories from emergent themes that were deemed relevant in explaining family firm innovation. We observed a general pattern connecting family firm innovation to long-term orientation in all our categories. We constantly compared coded documents and discussed possible conceptual patterns. These formed our first-order 
codes. During this step, NVivo facilitated the organization of all the codes that emerged from the data. NVivo 10 was chosen as it is widely considered the standard computer-aided qualitative data analysis software for analyzing qualitative data (Bazeley \& Jackson, 2013; Gibbs, 2002). Then, we searched for themes that could be grouped into higher-level codes. The higher-level categories were then refined through triangulation of sources (interviews, archival data, and observations) to produce a set of second-order codes. For example, categories containing instances in which participants talked about the importance of the past, tradition, and preservation of innovative actions were collapsed into a theme labeled "values of the past." The final coding step involved searching for links among second-order codes so that we could cluster these into aggregate dimensions. At this juncture, three dimensions emerged as constructs that appeared to be significant in explaining family firm innovative behavior and long-term orientation, namely conservation, persistence, and legacy. Figure 1 illustrates the structure and ordering of the data, from specific first-order codes to more general second-order codes and aggregate dimensions.

\section{"Insert Figure 1 Here"}

Throughout the process we iteratively analyzed the qualitative data by alternating between the qualitative evidence and an emerging structure of theoretical arguments that responded to established theory (Miles \& Huberman, 1994; Reay, 2014). As multiple coders were involved, to ensure coding consistency we developed a coding manual including definitions of each category and examples (Weber, 1990). Coding sample text, checking coding consistency, and revising the coding manual are part of an iterative process (Eisenhardt, 1989) and, as such, we continued the process until we achieved sufficient coding consistency (Weber, 1990). This approach enabled us to make stronger connections between our data and theory. This structured procedure for data collection and analysis, as well as the STEP semi-structured interview guide, enhanced the reliability of the research (Yin, 2003). 
Data coding was followed by a within-case study analysis of each of the five firms. We developed chronologically structured descriptions of each firm with relevant information on the family, the firm, and its innovation. The goal was to develop a rich understanding of the family firms through description and analysis of their innovations to date. Writing case descriptions assisted when some areas were unclear. In the last step, we engaged in cross-case analysis. The cross-case comparison allowed us to identify patterns among the firms. We then categorized and re-categorized our firms (Reay, 2014). Following this we used replication logic and investigated the similarity (or lack thereof) of patterns across the cases (Eisenhardt \& Graebner, 2007; Yin, 2003). Categorizing the data in this way reinforced an emergent cross-case pattern: family firm innovations are undertaken for the long-term. In other words, all of our firms were concerned with innovations that were aimed towards the creation of future value. After the cross-case analysis, we re-examined our data to ensure the emerging findings were consistent with the data and we conducted follow-up interviews with the CEOs to resolve any discrepancies and review the case histories with our participants. Our analysis of these follow-up interviews confirmed the pattern of innovation motives.

To enhance the robustness of our findings, we then collected additional data to determine whether the evidence gathered from our cases conformed with the evidence from an alternative data set outside the Irish context. For that, we used 27 worldwide STEP cases (see appendix) from the STEP case pool. Based on our initial knowledge of STEP case studies, we selected content-rich cases of family firms with explicit innovative activities. We reviewed all the cases carefully and searched for quotes reflecting innovative behavior. We followed the specific first-order codes to more general second-order codes and aggregate dimensions from our data structure highlighting those quotes that could explain family firm innovative behavior and long-term orientation. We then classified those quotes and cases around the three dimensions that previously emerged (conservation, persistence, and legacy). Our 
analysis of these cases replicated the pattern of innovation motives rather than yielding new insights; enabling a cross-validation of the patterns with a greater variety of family firms.

\section{Findings}

Our analysis revealed that the firms in our sample adopted three innovation patterns meaning that they were driven by three distinct sets of motives why to innovate. We labeled these conserving, persisting, and legacy-building, respectively. The first pattern (conserving) refers to firms in which innovations reflect the importance of the past, the family traditions, and reputation. The second category (persisting) denotes firms in which innovations were related to cumulative effort and patience for long-term rewards. The final pattern (legacybuilding) refers to firms in which innovations were associated with a certain pressure to perform and continue the family business and a desire to leave a mark for the next generation. Our first observation was that in all observed firms, innovative practices were conducted with the belief that they will have utility in the long run and will be of transgenerational benefit to the company. Our firms engaged in innovation driven by future motives aimed at achieving desirable future outcomes and accomplishing the firms' long-term goals. At this point, it also became apparent that each of the emerging innovation patterns led to specific innovation outcomes (refer to the innovation column in Tables 2-4). We observed four innovation outcomes for the firms in our sample: (1) product or service innovation, (2) process innovation, (3) marketing innovations, and (4) organizational innovations. First, the product innovations identified related to the creation of new products or services, or the modifications of existing ones, to meet the demands of the market (Zahra \& Covin, 1995). Second, process innovations refer to changes in the ways in which products or services are created and delivered (Tidd, Bessant, \& Pavitt, 2005), or the investment in and use of technology, machinery, and equipment to aid innovation. Third, we identified marketing innovations as those relating to changes in pricing strategies, market segmentation, promotions, distribution 
channels, and marketing information systems (Weerawardena, 2003). Finally, organizational innovations were concerned with changes in the organization's structure and processes (Armbruster, Bikfalvi, Kinkel, \& Lay, 2008). With these definitions in mind, Tables 2-4 provide exemplary quotes generated for each category and serve as the basis for the following section.

\section{Innovation Patterns}

Conserving. When searching for patterns in our data, we identified innovations which, aside from creating future value, were considered crucial for the continuity of the family business's reputation and traditions. These innovations were connected to the need for safeguarding the family's long-standing mission and reflected the importance of the past. In this category, the family values and reputation played a central role in new ways to preserve the family's history and traditions (see Table 2). An exemplar of this category is Case C, the oldest Irish family food company with a history spanning over 230 years. A leading producer of oat-based branded cereals, the family firm has run a mill in a rural village of Ireland since 1785. Efforts to strengthen the association between brand and long-established tradition have led to the proposed opening of a visitor center on the firm premises. The new service would act as brand promotion by further highlighting the history and tradition centric ethos of the firm:

I think we are going to have over two levels and maybe with a screen downstairs to do presentations. So, it's kind of a visitor center/conference center. You can maybe have a history of the plant for the visitors. (Financial Controller, G7)

In the late 1990s, a newly appointed marketing director commenced new marketing initiatives associated with efforts to highlight the family traditions and values and to enhance the family reputation, which resulted in a product mix that remains largely consistent.

As part of this new marketing direction, the company packaging has been redesigned to make space for a five-line narrative entitled: 'From Our Family to Yours' with the 
signature of the CEO featured underneath. These small touches act as a powerful reminder of the family behind the brand. (Sales \& Marketing Director, Non-Family)

In terms of trying to innovate and move with the times, we've grown a lot. We've added a lot of different lines. (International Business Development Manager, G7)

The brand's heritage was leveraged to provide the firm with a sustainable competitive advantage:

Our firm is a brand steeped in history in Ireland with unrivalled family expertise and oat milling tradition. (CEO, G6, News article 2015)

This marketing innovation strategy was also evident when launching new products outside Irish boundaries:

The Irish origin of oats backs up the positive image they have of Ireland as a point of origin for good quality food. (Sales \& Marketing Director, Non-Family, Irish Food Magazine, 2014)

Innovations in conserving firms were recognized as relating to the role of the founder, family tradition, family values, and reputation. There is a tendency to maintain traditional values as the core essence of the company. Across all these new products, there was a consistent mention of community connectedness. Illustrative examples of community embeddedness from Case $\mathrm{C}$ are apparent in the following quote:

Our Sales \& Marketing Director is developing a marketing strategy to draw more people's attention to the family business and the community. We are hiring local people and getting the oats from local suppliers, mostly within a hundred-mile radius. (Financial Controller, G7)

We believe the quintessential Irishness of the brand comes across in the new marketing campaign. (Sales \& Marketing Director, Non-Family)

Conserving innovations also included committed innovations aimed at the long-term sustainability of the community; such innovations are evident in Case C:

We will soon be installing a turbine in the mill. The turbine will add to our credentials as being an environmentally friendly producer in conjunction with our water turbine and our oat husk burning boiler. (CEO, G6)

We feel that sustainability is part of our DNA, it is an integral part of the way that we go about our business. We have noticed over the last five to ten years that whether it's 
business-to-business or business-to-consumer, customers are realizing the importance of the sustainability part of the business. (International Business Manager, G7, News article 2014)

To conclude, firms under this category emphasized the value of preservation, constancy, and longevity in their innovations, which were deeply rooted in the family. In particular, the preservation of tradition, family values, and reputation of the firm and the business family are of significance. In addition, all of the innovations under this category involved the development of new products, new services, or new marketing activities associated with family branding. Thus, we propose the following:

Proposition 1. Conserving multi-generational family firms will engage in innovations associated with the safeguarding of the family mission and tradition leading to new products, new services, or new marketing activities.

\section{"Insert Table 2 Here"}

Persisting. We distinguished the category of persisting as including those firms where innovations were characterized by cumulative effort and long-term rewards and associated with high levels of commitment and desire to succeed. Our case analysis showed that firms under this category, Case B and Case D, expressed a real intention to persevere over time, which drove the firm's long-lasting pursuit for success. These firms' innovations demonstrated the patience, discipline, and commitment of the families regarding future rewards (see Table 3).

For instance, Case B is a second-generation family business provider of water and wastewater treatment and pumping solutions in Ireland. The firm has a strong track record in bringing innovative technologies to the market and has been at the forefront regarding the design, manufacture, installation, commissioning, operation and maintenance of these technologies.

We were using mostly monopumps and then we started using centrifugal pumps and that changed the scene. We were buying from different places and, in 1974, he (co-founder) went to Italy. We were buying domestic pumps then from another company in Dublin. 
But we said: if they are bringing in pumps from Italy, why can't we do the same? (Cofounder, G1)

Innovations in Case D, a medium-size leading family business in the timber industry, have been characterized by persistence and intention to grow over time. The firm is currently managed by two brothers and co-CEOs of the third generation who have always focused on pushing the boundaries of forestry innovation and quality of home-grown timber through the early adoption of new sawmilling and scanning technology. In persisting with the improvement and growth of the business, they established a Sawmill Development Program (SDP) to enhance the business infrastructure and to cater for the increased demand for Ireland's maturing forests.

It's now up to the processor to ensure the timber wealth of our forests will generate economic growth. We need the cooperation of the state forest company to ensure ongoing continuity of supply to increase their share of the home market and to prepare for large future potential. (Excerpt from the Firm Biographical Book, 2013)

One of their latest innovations, evaluated on its potential for long-term value, is the first landing craft aimed at reducing the environmental impact of transporting logs.

Enormous time and energy has been invested in successfully implementing this innovative process [first timber landing craft] .... (Co-CEO, G3)

Persisting innovations were associated with a willingness to make investments in innovations with lengthy payback periods. As such, firms with innovations involving longterm investments, and benefits that can only be unlocked in the distant future, are classified under this category. In Case B, the firm, through a series of acquisitions and joint ventures, has expanded to become the multi-national company that it is today, with over 30 international markets. The family anticipates a large future pay-off for current innovative endeavors:

Predominantly, my own mission with them [partnership] is to become number one in the UK and Irish markets for water treatment. There is an oversupply of manufacturing capacity in the UK market. We are going to start buying out a few of the smaller companies over the next five years (Deputy MD, G2)

Case D experienced similar strategic growth. While a number of investments and new technologies were implemented during the 1960s, the most significant development has 
occurred through sawmill acquisitions under the management of the incumbent (third) generation. The strategy of growth and development through acquisition and diversification has been the hallmark of the business over a ten-year period from 1998 to 2008 .

The first acquisition happened in 1998. That was probably our first big move, and I would say it was the biggest move the company has ever taken. It was at the time that the business was the most explorative... We are at approximately 100 million turnover now. The next jump for acquisition for us would be a significant one; it just means we have to get structures in place so that we can grow the business as fast as we can. (Co-CEO, G3)

We built it [first acquisition plant] to be a super plant, a state-of-the-art plant. (Co-CEO, G3)

Our analysis suggested that persisting innovations may be especially important in times of adversity for the firm. New initiatives in response to market challenges or industry regulations allow the firm to adapt and persevere where it might otherwise potentially flounder.

Then we had a catastrophic collapse of the construction industry. We went through hell. It cut through the Irish business with a knife. We had to fight to survive week on week, trying to restructure the business, which we did thankfully, to get ourselves focused on exports. (Co-CEOs, G3)

In sum, our case study analysis identifies patterns within persisting firms of innovative behavior that generate future value from present hard effort and persistence and, therefore, encourage patience in the pursuit of future rewards. In addition, persisting innovations led to particular innovation outcomes, namely new technologies, new processes, and new partnerships and acquisitions. We therefore propose:

Proposition 2. Persisting multi-generational family firms will engage in innovations associated with cumulative effort and long-term rewards leading to new technologies, new processes, and new partnerships and acquisitions.

\section{"Insert Table 3 Here"}

Legacy-Building. In this category we identified firms where innovation activities were associated with the pressure to perform, the desire to leave a mark on the firm for the next generation and assure an enduring legacy. The cases under this category, Case A and Case E, 
pursued innovations with the intention to continue the legacy that the previous generation had built, while developing this legacy and ensuring its transfer to the following generation. We catalogued these innovations as legacy-building (see Table 4).

The goal of developing a legacy is associated with a long-term approach to firm decisionmaking. Case A represents a fourth generation family business and one of the leading tea brands in the Irish market. As the majority shareholder and the only family member directly involved in the business, the current Managing Director carries the sole responsibility of preserving the family wealth. Under his direction, the firm underwent some changes in its organizational structure. Given the maturity of the tea industry in Ireland, the incumbent CEO decided to diversify outside the tea business through a new holding investment structure.

I didn't want to be sitting here in 10 years' time and the tea business is falling down and my brothers and my sisters are saying, 'did you never think it might fall apart?' (Managing Director, G4)

So what we've done is we've diversified the family interests but not the tea business interests. We have renewed the organizational structure and we have created an investment company... we're investing to truly diversify the family business. So what we tried to do is to have two separate businesses, the tea business and another business which is the vehicle for investing, so innovation in terms of organizational structure. (Managing Director, G4)

While the tea business remains the core business and the family's legacy, the new business structure is a way to diversify family risk and preserve its wealth in the long term, as alluded to by the Managing Director: "the company is more valuable to the family than anybody else." Thus, the main objective is legacy-building innovation:

The new investment strategy is a question of credibility investment portfolio. We want to keep the tea business and pass it on, in better shape, to the next generation. (Finance Director, Non-Family)

The family in Case A comes from a line of politicians that stem back three generations, each of whom have focused their successful political careers on improving the lives of people within their community. As a family of politicians, they have always placed a great emphasis 
on managing their image and reputation. In this regard, the new business structure will serve as a way to continue the family legacy, and with it, the image of the family.

My father is a well-known politician. He was a particular type of politician, I know he is my father, but he was straightforward, honest, hardworking, and decent, trying always to do the right thing. That's the image that would have come across to the family, the family business and the products. Image is for everything, our name is on the box of tea. (Managing Director, G4)

The current CEO and owner perceives the firm as a patrimony to be afforded to his children. As such, the new business structure facilitates the transfer of this legacy to the second generation to ensure the continuity of the business.

What I'm trying to do or we're trying to do is a corporate restructuring ... we're going to have a quasi-group structure whereby the new family shareholding group is going to be shared equally by the children. (CEO, G1).

As a result, the family engaged professional advisors to help them identify ways to leverage the founder's legacy and to introduce new corporate governance initiatives into the family business.

[Because] I'm not going to live forever. I'm not, and I certainly ain't going to. What I want to do actually is - genuine basis is I want to leave my legacy. (CEO, G1).

We started with some professional advisors to get the mindset right for everybody in this new business structure process. (CEO, G1).

The current plan in Case $\mathrm{E}$ is to pass the ownership and management of the family business to the second generation once the new structure has been finalized and, consequently, an infrastructure for the founding legacy has been established.

In both of these examples, a major priority of the current managerial team is to leave a legacy for the future generation of the firm. Innovative behavior has focused on implementing new business structures that allow a legacy for the family business to be transferred. Therefore, this cluster includes innovations concerned with generating, adopting, and implementing innovations aimed at legacy-building. All of these innovations resulted in new business structures. Therefore, we suggest: 
Proposition 3. Legacy-building multi-generational family firms will engage in innovations associated with the desire to transfer a legacy to subsequent generations, leading to new business structures.

\section{"Insert Table 4 Here"}

\section{Family Firms' Innovation Pattern Framework}

Our investigation revealed that innovations in the studied firms were conducted with the belief that they will have value in the long-term and therefore will benefit future generations of the family; i.e. will have transgenerational value. However, the firms differed in their motives for innovating, and in their specific innovation patterns. To address whether the three approaches we identified - conserving, persisting, and legacy building — might correspond to other patterns or models in the literature, we searched the literature for existing frameworks that could help explain the observations emerging from our data about how a family firm that aspires to thrive through innovation perceives and plans for the future. That search eventually led us to the long-term orientation (LTO) construct (Lumpkin \& Brigham, 2011), not because it suggested innovation patterns, but because it outlined a framework of long-term logics that motivated transgenerational entrepreneurial activities such as innovation. As we further investigated LTO and its multi-dimensional framework, we realized that the different approaches to innovative behavior that we were seeing in our firms and the underlying motives could be linked to combinations of the LTO dimensions: futurity, continuity and perseverance.

The firms in our study engaged in innovation driven by transgenerational motives, aimed at achieving desirable future outcomes and accomplishing the business's long-term goals. Applying the LTO framework we aligned these transgenerational motives to the futurity dimension. Futurity involves evaluating the long-term consequences of decisions and actions with the belief that forecasting and planning for the future is valuable to the firm (Lumpkin \& Brigham, 2011). Firms exhibiting futurity typically focus on allocating resources to long-term 
goals and focusing research on achieving a future competitive edge (Venkatraman, 1989). We suggest that a firm concerned with innovation, i.e. concerned with generating, adopting, and implementing new ideas, processes, products, or services, aims for the creation of future value. It is reasonable to assume, given this close association, that futurity is at the heart of innovation and that all the innovations have the dimension of futurity embedded. We analyzed the cases, categorized along their innovation motives as discussed above along the LTO dimensions we observed for them. We found that conserving comprised elements of futurity and continuity; persisting firms comprised elements of futurity and perseverance; and legacybuilding firms comprised elements of futurity, continuity, and perseverance. Each of these variations corresponds to different conceptualizations of the LTO dimensions. These results form the basis for the development of our framework, as seen in Figure 2.

Firstly, multi-generational family firms that innovate to ensure the continuity of the family's mission and reputation, and from which innovation activities are based on family values and traditions, are categorized as conserving. Innovations in conserving family firms comprised of new products, new services, and new family branding (Proposition 1). Such innovations were concerned with enduring traditions that promote constancy and longevity, which were mainly driven by the need to maintain a long-lasting mission and reputation. In applying the LTO framework, we aligned these firms to the continuity dimension. The dimension of continuity encompasses the belief that the past informs the future, and highlights the importance of decisions and actions that are long-lasting. In essence, it is associated with efforts to retain the family mission and reputation, in addition to securing long-term relationships for the future benefit of the family business (Lumpkin \& Brigham, 2011). Continuity facilitates the link between the present and the past through which the family mission, history, value, and beliefs can be transferred across generations (Filser et al., 2017); 
a crucial element for innovation (Sirmon \& Hitt, 2003). In line with our observations, we propose the following:

Proposition 4. Innovative multi-generational family firms that are categorized as conserving will be more likely to identify with the LTO dimensions of futurity and continuity.

Secondly, we categorize multi-generational firms in which innovation activities deliver future value and rewards from cumulative effort, patience, and conscientious behavior as persisting. Persisting firms' innovation outcomes manifested in new technologies and processes, in addition to mergers and acquisitions (Proposition 2). Persisting firms' innovative behavior was associated with the perseverance dimension of the LTO framework. Perseverance is based on the belief that efforts made today will be valuable in the future because of their importance in generating long-term rewards (Brigham, Lumpkin, Payne, \& Zachary, 2014). While perseverance is needed for a firm's day-to-day survival, its effect creates value over time (Lumpkin \& Brigham, 2011). Perseverance and long-term rewards are common in family businesses, as reflected in their willingness to use patient capital (Sirmon \& Hitt, 2003) and make longer-term investments (Zellweger, 2007). Thus, perseverance is associated with an inclination towards making investments in innovations with lengthy payback periods. As such, innovative activities involving long-term investments with benefits that can only be unlocked in the distant future are classified under this category. Hence:

Proposition 5. Innovative multi-generational family firms that are categorized as persisting will be more likely to identify with the LTO dimensions of futurity and perseverance.

Lastly, firms in which innovations aimed to generate a legacy of value and reward for subsequent generations were classified as legacy-building. In our analysis, legacy-building firms lead to new business structures as innovation outcomes (Proposition 3). These firms innovated with the underlying intent to contribute to a desired legacy, which can be associated with a stewardship-centric approach. Family leaders are motivated to engage in these 
innovations in order to transfer a healthy growing firm to the next generation and, therefore, to benefit the family's broader interests. This is consistent with stewardship theory in that the family acts responsibly for the sake of the firm and its stakeholders (Miller, Le Breton-Miller, \& Scholnick, 2008). When a family aims to build a long-lasting legacy, all of the LTO dimensions-futurity, continuity, and perseverance-are present. A family legacy is associated with evaluating the long-range consequences of current actions, enabling efforts to build a long-lasting mission and reputation, and instilling the belief that it often takes time for endeavors to pay off. The concept of legacy is in reference to when an individual's behavior has implications for others in the future (Wade-Benzoni, Sondak, \& Galinsky, 2010). More specifically, a legacy can be defined as "an enduring meaning attached to one's identity and manifested in the impact that one has on others beyond the temporal constraints of the lifespan" (Fox, Tost, \& Wade-Benzoni, 2010, p. 153). In a business context, a legacy often ensures the firm is viable long-term, productive or generates even more value for the future. By leaving a legacy, an individual can be connected with the future (Wade-Benzoni et al., 2010); it is a symbolic form of immortality (Fox et al., 2010). The desire to leave a legacy is a motivational driver for entrepreneurial behavior (Fox et al., 2010). Building a lasting family business legacy requires incumbent leaders to make strategic decisions today that will be reflected in future outcomes. Moreover, leaving a legacy requires a long-term approach to organizational decision making. Thus, we suggest:

Proposition 6. Innovative multi-generational family firms that are categorized as legacy-building will be more likely to identify with the LTO dimensions of futurity, continuity, and perseverance.

To sum up, Figure 2 presents a model encompassing the innovation patterns of multigenerational family firms based on their long-term orientation. The emergent framework embraces the transgenerational context in which the innovation develops over time. 


\section{Discussion}

In this paper, we aim to provide a more nuanced understanding of why and how family firms innovate across generations through the lens of transgenerational entrepreneurship. The extant literature on family business suggests that family firms' long-term perspective can be a source of distinctiveness and competitive advantage (e.g., Miller \& Le Breton-Miller, 2005). Our investigation of the innovation patterns of a sample of multi-generational family firms has revealed that their specific long-term perspective can enhance our knowledge of why these firms innovate. Although we acknowledge that some family firms may innovate to reap short-term benefits by exploiting market gaps, we argue that the long-term view of family businesses is important in understanding innovation in these firms. Our study aims to introduce motives as a means for determining innovation patterns in multi-generational family firms. We develop a framework with three distinctive patterns based on the firms' distinctive long-term orientation. Although we can only speculate on the prevalence of these patterns, we believe that the archetypes identified merit consideration in innovation decisions. Much of the emphasis of innovation in family business research is focused on distinguishing between innovation in family and in non-family firms, and on the relationship between family firms and innovation (e.g., Block, 2012; Chrisman \& Patel, 2012; Llach \& Nordqvist, 2010). Our research shows that, at the most fundamental level, innovation motives are key to understanding innovation in family firms and, consequently, the emerging outcomes.

Several observations arise from our investigation. We find that the different components of the LTO construct are useful in grasping why innovation can manifest distinctively by context. Our evidence supports the notion that innovation is closely associated with futurity. More surprisingly, although all of the firms in our sample explicitly acknowledged their future orientation, they differed in the specific aspects of innovation. Thus, more notably, we identified a greater holistic view of innovation in cases when futurity is coupled with different 
LTO dimensions. In doing so, we extend recent research on family business innovation, providing a nuanced picture of why multi-generational family firms innovate. The leitmotif embodied by our theorizing is that long-term orientation is of substantial importance in understanding innovation in family firms. We believe a key contribution of our work is to suggest that long-term orientation is not only compatible with innovation, but may also be an important shaper of innovative behavior in family firms. Our results may serve as initial evidence that specific innovation motives in family firms are associated with certain LTO dimensions, thus suggesting that LTO is a source of heterogeneity in family firms and that it leads, for instance, to variance in innovation.

Furthermore, we introduce motives as a means for determining the innovation patterns of multi-generational family firms and suggest that their long-term view acts as a source of legitimacy for innovation decisions. We suggest that family firms' long-term view has consistent patterns of association with their innovation motives which influence how subsequent generations engage in innovation, thereby promoting transgenerational entrepreneurship. The propositions and framework that we developed using a transgenerational entrepreneurship lens provide significant insight into the sorts of innovation patterns that multi-generational family firms employ.

Moreover, our focus on the LTO construct contributes to family business and entrepreneurship research by exploring a temporal construct in order to understand innovation in family firms (Sharma et al., 2014) and to integrate it with the transgenerational entrepreneurship perspective. Our findings suggest that, for family firms that aspire to be transgenerational, innovation enhances their ability to be entrepreneurial over the long run. Previous research has called for a greater understanding of the long-term perspective and its implications (e.g., Hofstede, 1980; James, 1999; Miller \& Friesen, 1982). However, since Lumpkin and Brigham's (2011) work, few attempts have been made to refine the construct. 
We draw upon LTO dimensions as a means to explain heterogeneous innovative behavior in family firms and, therefore, challenge the view of family firms as homogeneous enterprises (Chua et al., 2012; Kraiczy et al., 2014). By providing a detailed account of how LTO dimensions manifest, we explore this phenomenon as a multi-dimensional construct (as opposed to prior research, which studied it as unidimensional), providing a more nuanced understanding of family firm innovation patterns.

Additionally, we extend the work of De Massis and colleagues (2014), which suggests that for a family firm to display a family-oriented particularistic behavior, the ability and willingness of the family is required. Our cases showed not only that family involvement was a necessary contributor to adopting a long-term view, but also that the willingness of the family (in terms of intention) and the ability of the family managers (in terms of discretion) were needed to pursue a long-term orientation. De Massis et al.'s (2014) sufficiency model also helps to explain the limitations in the development of a theory of the family firm, by showing that particularistic behaviors exist among firms with family involvement due to the willingness and ability linked to the involved family, and not to concentrated ownership. In relation to the pursuit of long-term orientation, if willingness is assumed to be invariant, ability needs to be established and explained vis-à-vis the family's involvement and not concentrated ownership, per se. In other words, if the differences are not attributed to family involvement, the debate does not revolve around family firms, but rather around ownership. If, on the other hand, ability to pursue a long-term orientation is invariant, no particularistic behavior is observable and family firms behave as non-family firms do. Hence, in this situation, willingness must be considered as a means of explaining the particularistic behavior of family firms - specifically, why they pursue long-term goals or why they innovate.

Finally, our results also have practical implications. On the one hand, incumbent family business practitioners seeking to remain successful across generations need to recognize and 
understand the long-term consequences of their current actions. Our research provides a practical framework to educate next-generation family members on the history of the firm and the potential corporate gains achievable from understanding and leveraging the past, present, and future of the firm, and on making informed strategic decisions that affect both family and business interests. On the other hand, this study highlights that innovation decisions in family firms might not always be underpinned by rational economic assumptions. Long-term oriented family firms have non-economic motives, and the pursuit of those motives may lead to decisions and outcomes that diverge substantially from the decisions and outcomes expected in non-family firms, where non-economic motives are less important. Our research provides non-family managers with a framework for understanding innovation-related family firm motives, which are often grounded in firm history, economic and non-economic goals, and concern for the next generation.

\section{Limitations and Future Research}

Our research is not without limitations. Our findings are based on data collected from successful multi-generational family firms that have taken part in the STEP project. As per STEP criteria, we know that these firms aspire to pass the business on to the next generation. We sought to inductively discover common patterns in the data, but because we studied only innovative firms, we cannot speak to the determinants of innovation (Handler, 1989). Confining the study to successful multi-generational family firms may limit our findings' generalizability. We understand that our interpretations and the categories we derived represent analytical rather than statistical generalizations (Yin, 2009); therefore, a useful way to increase generalizability would be to examine our framework across a wider spectrum of family firms outside the STEP criteria, facilitating broader perceptions of how innovative behavior in family firms is shaped by their long-term orientation. Additionally, our main study relied on only five cases; this allowed a detailed and contextually rich analysis of the 
complex process of innovation in family firms (Yin, 2009). When selecting the cases we made sure to cover variance with regard to firms' age, size, industry, turnover, and generation. The number of cases studied is in line with Eisenhardt's suggestions (1989) when elaborating on optimum case numbers for multi-case studies. Furthermore, to enhance the robustness of our findings, we cross-validate our pattern of innovation motives in an alternative data set comprising 27 worldwide STEP cases.

Despite these limitations, our study highlights important avenues for future research. One additional route could be the development of longitudinal studies that explore how innovation practices evolve as a family firm's long-term perspective changes over time. Such studies could contribute further by providing insights into the innovation of family firms at different points in time or in different generations. It would also be interesting to investigate whether our suggested innovation motives tend to lead to certain innovation patterns regarding incremental versus radical innovations.

This research also enriches the theoretical lens through which researchers can examine family firms by suggesting that transgenerational entrepreneurship is a purposeful approach to understanding innovation behavior in family firms. Transgenerational entrepreneurship focuses on how the family impacts the entrepreneurial activity and longevity of the firm (Zellweger \& Sieger, 2012). While researchers have studied possible drivers of successful transgenerational entrepreneurship, there is limited research that adopts this approach as a lens for understanding other family firm concerns. Therefore, future research could adopt a transgenerational entrepreneurial lens to explain other idiosyncratic behavior in family firms, such as strategic decision-making, talent management (family and non-family), and capital structures.

Another potential avenue for future inquiry involves exploring how the incumbent generation's innovative behavior influences future generations. Intergenerational theorists 
contend that the incumbent generation's behavior affects subsequent generations (Barry, 1989; Weiss, 1989), and that obligations to future generations stem from the fortune received from past generations (Wade-Benzoni, 2002). As the long-term implications of intergenerational decisions are temporally and personally removed from the decision-makers, non-family firms would potentially have different perspectives on how clan-like behaviors are instituted. As such, future studies of family firm innovation and intergenerational reciprocity may help identify differences in the innovation behaviors between family and non-family firms.

To complement our study, it would also be interesting to investigate whether adopting a long-term orientation has a positive effect on the performance and competitive advantages of family firms generally. While prior research supports this view (Miller \& Le Breton-Miller, 2005), additional empirical investigation is needed, particularly to explore the non-economic significance of long-term orientation. Previous research suggests that strategic decisions in family firms are often driven by non-economic goals (Gomez-Mejia et al., 2007). Long-term orientation in family firms may be especially important in achieving non-economic goals due to the planning, patience, and discipline that they typically require. Reconciling the long-term view of family firms with their pursuit of non-economic goals is paramount to advancing both theory and practice in the family business field.

In future, researchers might also focus on the differences across family firms that explain why some firms are inclined to innovate but others are not, despite having a long-term orientation. One explanation might be imprinting by previous generations, but there could be other considerations, such as industry conditions in which innovation is less vital for survival, or resource constraints that inhibit investments in innovation activity. A related topic for future research is the extent to which the innovation patterns that family firms exhibit reflect the type of innovation they engage in. It could be argued, for example, that both conserving 
innovation and persisting innovation are consistent with incremental approaches to innovation, which are the most common type of innovation. By contrast, for a family business to develop innovations that are truly legacy-building, an even longer time frame may be needed, along with more radical approaches to innovation.

\section{Conclusion}

Our study illuminates the importance and diversity of innovation in multi-generational family firms based on their long-term perspective. We argue that ignoring an important distinctiveness of family firms, their long-term orientation, can be problematic given that our understanding of family firms' innovative behavior is limited. Gaining an even deeper understanding of the impact of temporal constructs on family firm innovation can provide additional theoretical and practical insights for the family business literature. We invite researchers to continue developing this important line of research.

\section{References}

Aldrich, H. E., Renzulli, L., \& Langton, N. (1998). Passing on privilege: Resources provided by self-employed parents to their self-employed children. In K. Leicht (Ed.), Research in Social Stratification and Mobility (Vol. 16, pp. 291-318). Greenwich, CT: JAI Press.

Anderson, R. C., \& Reeb, D. M. (2003). Founding-family ownership and firm performance: Evidence from the S \& P 500. The Journal of Finance, 58(3), 1301-1328.

Andres, C. (2011). Family ownership, financing constraints and investment decisions. Applied Financial Economics, 21(22), 1641-1659.

Armbruster, H., Bikfalvi, A., Kinkel, S., \& Lay, G. (2008). Organizational innovation: The challenge of measuring non-technical innovation in large-scale surveys. Technovation, 28(10), 644-657.

Arregle, J., Hitt, M. A., Sirmon, D. G., \& Very, P. (2007). The development of organizational social capital: Attributes of family firms. Journal of Management Studies, 44(1), 73-95.

Astrachan, J. H., \& Jaskiewicz, P. (2008). Emotional returns and emotional costs in privately held family businesses: Advancing traditional business valuation. Family Business Review, 21(2), 139-149.

Bammens, Y., Notelaers, G., \& Van Gils, A. (2015). Implications of family business employment for employees' innovative work involvement. Family Business Review, 28(2), 123-144.

Barry, B. (1989). Theories of Justice. Berkeley, CA: University of California Press.

Bazeley, P., \& Jackson, K. (Eds.). (2013). Qualitative data analysis with NVivo. Thousand Oaks, CA: Sage Limited. 
Bergfeld, M. M., \& Weber F. M. (2011). Dynasties of innovation: Highly performing German family firms and the owners' role for innovation. International Journal of Entrepreneurship and Innovation Management, 13(1), 80-94.

Bessant, J., Lamming, R., Noke, H., \& Phillips, W. (2005). Managing innovation beyond the steady state. Technovation, 25(12), 1366-1376.

Block, J. H. (2012). R\&D investments in family and founder firms: An agency perspective. Journal of Business Venturing, 27(2), 248-265.

Block, J., Miller, D., Jaskiewicz, P., \& Spiegel, F. (2013). Economic and technological importance of innovations in large family and founder firms: an analysis of patent data. Family Business Review, 26(2), 180-199.

Blundell, R., Griffiths, R., \& Van Reenen, J. (1999). Market share, market value and innovation in a panel of British manufacturing firms. Review of Economic Studies, 66(3), $529-554$.

Brigham, K. H., Lumpkin, G. T., Payne, G. T., \& Zachary, M. A. (2014). Researching longterm orientation: A validation study and recommendations for future research. Family Business Review, 27(1), 72-78.

Carnes, C. M., \& Ireland, R. D. (2013). Familiness and innovation: Resource bundling as the missing link. Entrepreneurship Theory \& Practice, 37(6), 1399-1419.

Carney, M. (2005). Corporate governance and competitive advantage in family-controlled firms. Entrepreneurship \& Regional Development, 29(3), 249-265.

Cassia, L., Massis, A. De., \& Pizzurno, E. (2012). Strategic innovation and new product development in family firms: An empirically grounded theoretical framework. International Journal of Entrepreneurial Behaviour \& Research, 18(2), 198-232.

Chrisman, J. J., Chua, J. H., De Massis, A., Frattini, F., \& Wright, M. (2015). The ability and willingness paradox in family firm innovation. Journal of Product Innovation Management, 32(3), 310-318.

Chrisman, J. J., \& Patel, P. C. (2012). Variations in R\&D investments of family and nonfamily firms: Behavioral agency and myopic loss aversion perspectives. Academy of Management Journal, 55(4), 976-997.

Chua, J. H., Chrisman, J. J., \& Sharma, P. (1999). Defining the family business by behavior. Family Business Review, 23(4), 19-39.

Chua, J. H., Chrisman, J. J., Steier, L. P., \& Rau, S. B. (2012). Sources of heterogeneity in family firms: An introduction. Entrepreneurship Theory and Practice, 36(6), 1103-1113.

Craig, J. B., Cassar, G., \& Moores, K. (2006). A 10-year longitudinal investigation of strategy, systems, and environment on innovation in family firms. Family Business Review, 19(1), 1- 10.

Craig, J. B., \& Dibrell, C. (2006). The natural environment, innovation, and firm performance: A comparative study. Family Business Review, 19(4), 275-288.

Craig, J. B., Dibrell, C., \& Davis, P. S. (2008). Leveraging family-based brand identity to enhance firm competitiveness and performance in family businesses. Journal of Small Business Management, 46(3), 351-371.

Creswell, J. W. (2009). Research design: Qualitative, quantitative, and mixed methods approaches (3rd Ed). Thousand Oaks, CA: Sage Publications. 
Damanpour, F. (1991). Organizational innovation: A meta-analysis of effects of determinants and moderators. Academy of Management Journal, 34(3), 555-590.

De Massis, A., Frattini, F., Kotlar, J., Petruzzelli, M. A., \& Wright, M. (2016). Innovation through tradition. Academy of Management Perspectives, 30(1), 93-116.

De Massis, A., Frattini, F., \& Lichtenthaler, U. (2013). Research on technological innovation in family firms: Present debates and future directions. Family Business Review, 26(1), $10-31$.

De Massis, A., \& Kotlar, J. (2014). The case study method in family business research: Guidelines for qualitative scholarship. Journal of Family Business Strategy, 5(1),15-29.

De Massis, A., Kotlar, J., Chua, J. H., \& Chrisman, J. J. (2014). Ability and willingness as sufficiency conditions for family-oriented particularistic behavior: Implications for theory and empirical studies. Journal of Small Business Management, 52(2), 344-364.

Drakopoulou Dodd, S., Anderson, A., \& Jack, S. (2013). Being in time and the family owned firm. Scandinavian Journal of Management, 29(1), 35-47.

Duran, P., Kammerlander, N., van Essen, M., \& Zellweger, T. (2016). Doing more with less: Innovation input and output in family firms. Academy of Management Journal, 59(4), 175 .

Eddleston , K. A., Kellermanns, F. W., \& Zellweger, T. M. (2012). Exploring entrepreneurial behaviour of family firms: Does the stewardship perspective explain difference? Entrepreneurship Theory and Practice, 36(2), 347-367.

Eisenhardt, K. M. (1989). Building theories from case study research. Academy of Management Review, 14(4), 532-550.

Eisenhardt, K. M., \& Graebner, M. E. (2007). Theory building from cases: Opportunities and challenges. Academy of Management Journal, 50(1), 25-32.

Filser, M., De Massis, A., Gast, J., Kraus, S., \& Niemand, T. (2017). Tracing the roots of innovativeness in family SMEs: The effect of family functionality and socioemotional wealth. Journal of Product Innovation Management, forthcoming. DOI: 10.1111/jpim.12433

Fox, M., Tost, L. P., \& Wade-Benzoni, K. A. (2010). The legacy motive: A catalyst for sustainable decision making in organizations. Business Ethics Quarterly, 20(2), 153-185.

Gibbs, G. R. (2002). Qualitative data analysis: Explorations with NVivo. Buckingham, UK: Open University Press.

Gomez-Mejia, L. R., Haynes, K. T., Núñez-Nickel, M., Jacobson, K. J. L., \& Moyanofuentes, J. (2007). Socioemotional wealth and business risks in family-controlled firms: Evidence from Spanish olive oil mills. Administrative Science Quarterly, 52(1), 106-137.

Greve, H. R. (2009). Bigger and safer: The diffusion of competitive advantage. Strategic Management Journal, 30(1), 1-23.

Habbershon, T. G. \& Pistrui, J. (2002). Enterprising families domain: Family-influenced ownership groups in pursuit of transgenerational wealth. Family Business Review, 15(3), 223-237.

Habbershon, T. G., Williams, M., \& MacMillan, I. C. (2003). A unified systems perspective of family firm performance. Journal of Business Venturing, 18(4), 451-465.

Handler, W. C. (1989). Methodological issues and considerations in studying family 
businesses. Family Business Review, 2(3), 257-276.

Hofstede, G. (1980). Culture's consequences: International differences in world-related values. Beverly Hills, CA: Sage.

Hult, G. T. M., Hurley, R. F., \& Knight, G. A. (2004). Innovativeness: Its antecedents and impact on business performance. Industrial Marketing Management, 33(5), 429-438.

James, H. S. (1999). Owner as manager, extended horizons and the family firm. International Journal of the Economics of Business, 6(1), 41-55.

Jaskiewicz, P., Combs, J. G., \& Rau, S. B. (2015). Journal of Business Venturing entrepreneurial legacy: Toward a theory of how some family firms nurture transgenerational entrepreneurship. Journal of Business Venturing, 30(1), 29-49.

Johannessen, J. A., Olsen, B., \& Lumpkin, G. T. (2001). Innovation as newness: What is new, how new, and new to whom? European Journal of Innovation Management, 4(1), 20-31.

Kammerlander, N., Dessi, C., Bird, M., Floris, M., \& Murru, A. (2015). The impact of shared stories on family firm innovation: A multicase study. Family Business Review, 28(4), $332-354$.

Kammerlander, N., \& Ganter, M. (2015). An attention-based view of family firm adaptation to discontinuous technological change: Exploring the role of family CEOs' noneconomic goals. Journal of Product Innovation Management, 32(3), 361-383.

Kellermanns, F. W., \& Eddleston, K. A. (2006). Corporate entrepreneurship in family firms: A family perspective. Entrepreneurship Theory and Practice, 30(6), 809-30.

Kellermanns, F. W., Eddleston, K. A., Barnett, T., \& Pearson, A. W. (2008). An exploratory study of family member characteristics and involvement: Effects on entrepreneurial behavior in the family firm. Family Business Review, 21(1), 1-14.

Kellermanns, F. W., Eddleston, K., Sarathy, R., \& Murphy, F. (2012). Innovativeness in family firms: A family influence perspective. Small Business Economics, 38(1), 85-101.

Kets de Vries, M. (1993). Human dilemmas in family business. London, UK: Routledge.

Koenig, A., Kammerlander, N., \& Enders, A. (2013). The Family Innovator's Dilemma: How Family Influence Affects the Adoption of Discontinuous Technologies by Incumbent Firms. Academy of Management Review, 38(3), 418-441.

Kotlar, J., De Massis, A., Frattini, F., Bianchi, M., \& Fang, H. (2013). Technology acquisition in family and nonfamily firms: A longitudinal analysis of Spanish manufacturing firms. Journal of Product Innovation Management, 30(6), 1073-1088.

Kraiczy, N. D., Hack, A., \& Kellermanns, F. W. (2014). New product portfolio performance in family firms. Journal of Business Research, 67(6), 1065-1073.

Laforet, S. (2013). Innovation characteristics of young and old family-owned businesses. Journal of Small Business and Enterprise Development, 20(1), 204-224.

Le Breton-Miller, I., \& Miller, D. (2011). Commentary: Family firms and the advantage of multitemporality. Entrepreneurship Theory and Practice, 35(6), 1171-1177.

Li, Z., \& Daspit, J. J. (2016). Understanding family firm innovation heterogeneity: A typology of family governance and socioemotional wealth intentions. Journal of Family Business Management, 6(2), 103-121.

Llach, J., \& Nordqvist, M. (2010). Innovation in family and non-family businesses: A 
resource perspective. International Journal of Entrepreneurial Venturing, 2(3-4), 381399.

Lumpkin, G. T., \& Brigham, K. H. (2011). Long-term orientation and intertemporal choice in family firms. Entrepreneurship Theory and Practice, 35(6), 1149-1169.

Lumpkin, G. T., \& Dess, G. (1996). Clarifying the entrepreneurial orientation construct and linking it to performance. Academy of Management Review, 21(1), 135-172.

Lumpkin, G. T., Brigham, K. H., \& Moss, T. W. (2010). Long-term orientation: Implications for the entrepreneurial orientation and performance of family businesses. Entrepreneurship \& Regional Development, 22(3-4), 241-264.

Matzler, K., Veider, V., Hautz, J., \& Stadler, C. (2015). The impact of family ownership, management and governance on innovation. Journal of Product Innovation Management, $32(3), 319-333$.

McCann, J. E., Leon-Guerrero, A. Y., \& Haley, J. D. (2001). Strategic goals and practices of innovative family businesses. Journal of Small Business Management, 39(1), 50-59.

Merriam, S. B. (1998). Qualitative research and case study applications in education. San Francisco, CA: Jossey-Bass.

Miles, M., \& Huberman, M. (1994). Qualitative data analysis. Thousand Oaks, CA: Sage Publications.

Miller, D., \& Friesen, P. H. (1982). Innovation in conservative and entrepreneurial firms: Two models of strategic momentum. Strategic Management Journal, 3(1), 1-25.

Miller, D., \& Le Breton-Miller, I. (2005). Managing for the long run: Lessons in competitive advantage from great family businesses. Boston, MA: Harvard.

Miller, D., Le Breton-Miller, I., Lester, R. H., \& Cannella, A. A. Jr. (2007). Are family firms really superior performers? Journal of Corporate Finance, 13(5), 829-858.

Miller, D., Le Breton-Miller, I., \& Scholnick, B. (2008). Stewardship vs. stagnation: An empirical comparison of small family and non-family businesses. Journal of Management Studies, 45(1), 51-78.

Naldi, L., Nordqvist, M., Sjöberg, K., \& Wiklund, J. (2007). Entrepreneurial orientation, risk taking, and performance in family firms. Family Business Review, 20(1), 33-48.

Nohria, N., \& Gulati, R. (1996). Is slack good or bad for innovation. Academy of Management Journal, 39(5), 1245-1264.

Nordqvist, M., Habbershon, T. G., \& Melin, L. (2008). Transgenerational entrepreneurship: Exploring EO in family firms. In H. Landström, H. Crijns and E. Laveren (Eds.), Entrepreneurship, sustainable growth and performance: frontiers in European entrepreneurship research (pp. 93-116). Cheltenham, UK and Northampton, MA, USA: Edward Elgar Publishing.

Nordqvist, M., Hall, A., \& Melin, L. (2009). Qualitative research in family business studies: The usefulness of the interpretive approach. Journal of Management \& Organization, 15(3), 294-308.

Nordqvist, M., \& Zellweger, T. (2010). Transgenerational entrepreneurship: Exploring growth and performance in family firms across generations. Cheltenham, UK: Edward Elgar.

Reay, T. (2014). Publishing qualitative research. Family Business Review, 27(2), 95-102. 
Rod, I. (2016). Disentangling the family firm's innovation process: A systematic review. Journal of Family Business Strategy, 7(3), 185-201.

Schumpeter, J. (1934). Capitalism, socialism, and democracy. New York, NY: Harper \& Row.

Sharma, P., Salvato, C., \& Reay, T. (2014). Temporal dimensions of family enterprise research. Family Business Review, 27(1), 10-19.

Sirmon, D. G., \& Hitt, M. A. (2003). Managing resources: Linking unique resources, management, and wealth creation in family firms. Entrepreneurship Theory and Practice, 27(4), 339-358.

Slevin, D. P., \& Covin, J. G. (1995). Entrepreneurship as firm behavior: A research model. Advances in Entrepreneurship, Firm Emergence, and Growth, 2, 175-224.

Subramaniam, M., \& Youndt, M. A. (2005). The influence of intellectual capital on the types on innovative capabilities. Academy of Management Journal, 48(3), 450-463.

Thompson, V. A. (1965). Bureaucracy and innovation. Administrative Science Quarterly, 10(1), 1-20.

Tidd, J., Bessant, J., \& Pavitt, K. (2005), Managing innovation: Integrating technological, market and organizational change (3rd Ed.). Chichester, UK: Wiley.

Tsai, K.-H., \& Yang, S.-Y. (2012). The contingent value of firm innovativeness for business performance under environmental turbulence. International Entrepreneurship and Management Journal, 10(2), 343-366.

Van Gils, A., Dibrell, C., Neubaum, D. O., \& Craig, J. B. (2014). Social issues in the family enterprise. Family Business Review, 27(3), 193-205.

Venkatraman, N. (1989). Strategic orientation of business enterprises: The construct, dimensionality, and measurement. Management Science, 35(8), 942-962.

Villalonga, B., \& Amit, R. (2010). Family control of firms and industries. Financial Management, 39(3), 863-904.

Wade-Benzoni, K. A. (2002). A golden rule over time: Reciprocity in intergenerational allocation decisions. Academy of Management Journal, 45(5), 1011-1028.

Wade-Benzoni, K. A., Sondak, H., \& Galinsky, A. (2010). Leaving a legacy: Intergenerational allocations of benefits and burdens. Business Ethics Quarterly, 20(1), $7-34$.

Ward, J. L. (2004). Perpetuating the family business: 50 lessons learned from long-lasting, successful families in business. Hampshire, UK: Palgrave Macmillan.

Weber, R. P. (1990). Basic content analysis (2nd Ed.). Newbury Park, CA: Sage.

Weerawardena, J. (2003). Exploring the role of market learning capability in competitive strategy. European Journal of Marketing, 37(3/4), 407-429.

Weiss, E. B. (1989). In fairness to future generations: International law, common patrimony, and intergenerational equity. New York, NY: Transnational Publishers.

Wiklund, J., \& Shepherd, D. (2005). Entrepreneurial orientation and small business performance: A configurational approach. Journal of Business Venturing, 20(1), 71-91.

Yin, R. K. (2003). Applications of case study research (2nd Ed.). Thousand Oaks, CA: Sage Publications. 
Yin, R. K. (2009). Case study research: Design and methods (4th Ed.). Thousand Oaks, CA: Sage Publications.

Zahra, S. A. (2003). International expansion of U.S. manufacturing family businesses: The effect of ownership and involvement. Journal of Business Venturing, 18(4), 495-512.

Zahra, S. \& Covin, J. (1995). Contextual influence on the corporate entrepreneurshipperformance relationship: A longitudinal analysis. Journal of Business Venturing, 10(1), $43-58$.

Zahra, S. A., Hayton, J. C., \& Salvato, C. (2004). Entrepreneurship in family vs. non-family firms: A resource-based analysis of the effect of organizational culture. Entrepreneurship Theory and Practice, 28(4), 363-381.

Zellweger, T. M. (2007). Time horizon, costs of equity capital, and generic investment strategies of firms. Family Business Review, 20(1), 1-15.

Zellweger, T., Eddleston, K., \& Kellermanns, F. W. (2010). Exploring the concept of familiness: Introducing family firm identity. Journal of Family Business Strategy, 1(1), $54-63$.

Zellweger, T. M., Nason, R. S., \& Nordqvist, M. (2011). From longevity of firms to transgenerational entrepreneurship of families: Introducing family entrepreneurial orientation. Family Business Review, 25(2), 136-155.

Zellweger, T. M. \& Sieger, P. (2012). Entrepreneurial orientation in long-lived family firms. Small Business Economics, 38(1), 67-84.

Table 1. Description of the Firms

\begin{tabular}{|c|c|c|c|c|c|}
\hline Firm & Case A & Case B & Case C & Case D & Case $\mathbf{E}$ \\
\hline Industry & $\begin{array}{c}\text { Hot beverages: } \\
\text { Tea }\end{array}$ & $\begin{array}{l}\text { Water, wastewater } \\
\text { treatment }\end{array}$ & $\begin{array}{l}\text { Food (oat-based } \\
\text { branded cereals) }\end{array}$ & Timber: Sawmilling & $\begin{array}{l}\text { Agricultural } \\
\text { machinery }\end{array}$ \\
\hline Year Founded & 1901 & 1968 & 1785 & 1913 & 1996 (bought) \\
\hline Generation & 4 th & $2^{\text {nd }}$ & $7^{\text {th }}$ & $3 \mathrm{rd}$ & 2nd \\
\hline Family Ownership & $100 \%$ & $100 \%$ & $100 \%$ & $100 \%$ & $100 \%$ \\
\hline No. of Employees & 72 & 300 & 52 & 260 & 50 \\
\hline Turnover (USD) & Private & $72 \mathrm{M}$ & $22 \mathrm{M}$ & $110 \mathrm{M}$ & $11 \mathrm{M}$ \\
\hline Family CEO & Yes & Yes & Yes & Yes & Yes \\
\hline $\begin{array}{l}\text { No. of interviews/ } \\
\text { follow-up interview }\end{array}$ & $6 / 1$ & $8 / 1$ & $5 / 1$ & $7 / 1$ & $12 / 0$ \\
\hline No. of participants & 6 & 8 & 5 & 7 & 12 \\
\hline $\begin{array}{l}\text { Duration of } \\
\text { interviews (min) }\end{array}$ & 240 & 462 & 251 & 396 & 492 \\
\hline No. pages transcripts & 89 & 147 & 81 & 157 & 159 \\
\hline \multirow{8}{*}{ Archival sources } & \multirow{8}{*}{$\begin{array}{l}\text { Media Articles } \\
(39) \\
\text { Company Reports } \\
(19) \\
\text { TV/Radio (4) } \\
\text { Videos (29) } \\
\text { Prof. Profiles (2) } \\
\text { Corp. Webpage } \\
(2)\end{array}$} & Media Articles (9) & Media Articles (8) & Media Articles (47) & Media Articles (9) \\
\hline & & \multirow{4}{*}{$\begin{array}{l}\text { Company Reports } \\
(32) \\
\text { Corp. Presentations } \\
\text { (4) }\end{array}$} & Company Reports (5) & Corp. Presentations (1) & \multirow{5}{*}{$\begin{array}{l}\text { Corp. Presentations } \\
\text { (2) } \\
\text { Videos (42) } \\
\text { Prof. Profiles (4) } \\
\text { Corp. Webpage (2) }\end{array}$} \\
\hline & & & Corp. Presentations (1) & TV/Radio (1) & \\
\hline & & & TV/Radio (4) & Videos (6) & \\
\hline & & & \multirow{4}{*}{$\begin{array}{l}\text { Videos (17) } \\
\text { Prof. Profiles (3) } \\
\text { Corp. Webpage (2) }\end{array}$} & Company History Book & \\
\hline & & Videos (8) & & (1) & \\
\hline & & Prof. Profiles (3) & & Prof. Profiles (2) & \\
\hline & & Corp. Webpage (1) & & Corp. Webpage (1) & \\
\hline \multirow[b]{2}{*}{ Observations } & Plant tours (1) & Plant tours (2) & Plant tours (2) & Plant tours (2) & Plant tours (2) \\
\hline & & $\begin{array}{l}\text { Corp. presentations } \\
\& \text { events }(5)\end{array}$ & $\begin{array}{l}\text { Corp. presentations \& } \\
\text { events }(5)\end{array}$ & $\begin{array}{l}\text { Corp. presentations \& } \\
\text { events (4) }\end{array}$ & $\begin{array}{l}\text { Corp. presentations } \\
\& \text { events (2) }\end{array}$ \\
\hline
\end{tabular}


Figure 1. Data Structure

First-order codes
Second-order themes

Aggregate theoretical dimensions
- Articulation of discipline and self-control

- Expressions of high levels of commitment

- Expressions of desire to succeed in the long-term

- Indications of hard work and persistence

- $\quad$ Presence of patient capital and long-term investments in innovations

- Demonstrate patience for future rewards

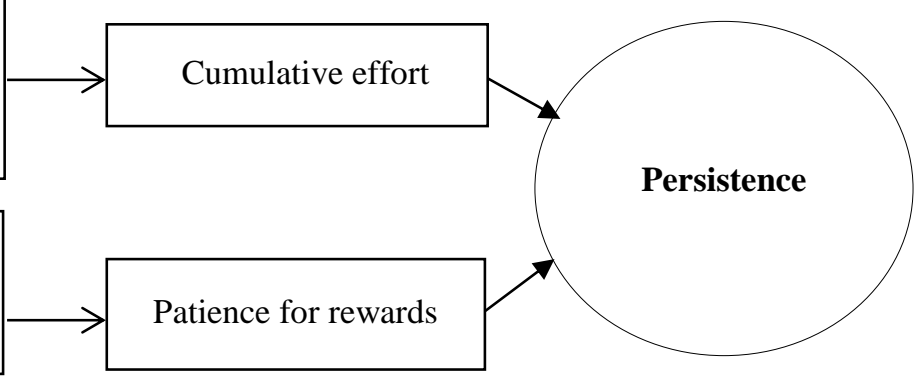

- Articulation of importance to the past for future actions

- Recognizing lasting effect of founders or previous generations in current innovative actions

- Expressions that value tradition and preservation

- Statements related to promote tradition and values in the family business

- Expressions of desire to build a long-lasting mission

- Expressions of importance attached to reputation

- Concern about damaging family reputation

- Expressions that link family association with product branding

- Presence of family status in marketing activities

- Statements that refer to how other businesses and customers value dealing with a family business

- Identification of the need to step out of the previous generation's shadow

- Statements referring to a sense of obligation to improve and grow the business

- Expression of desire to contribute to the longevity of the family business

- References to the entrepreneurial behavior of previous generations

- Statements aligning drive for entrepreneurial desire with those of previous generations

- Expressions of desire to retain the business within the family

- Statements about aspiration of control or ownership for next generation
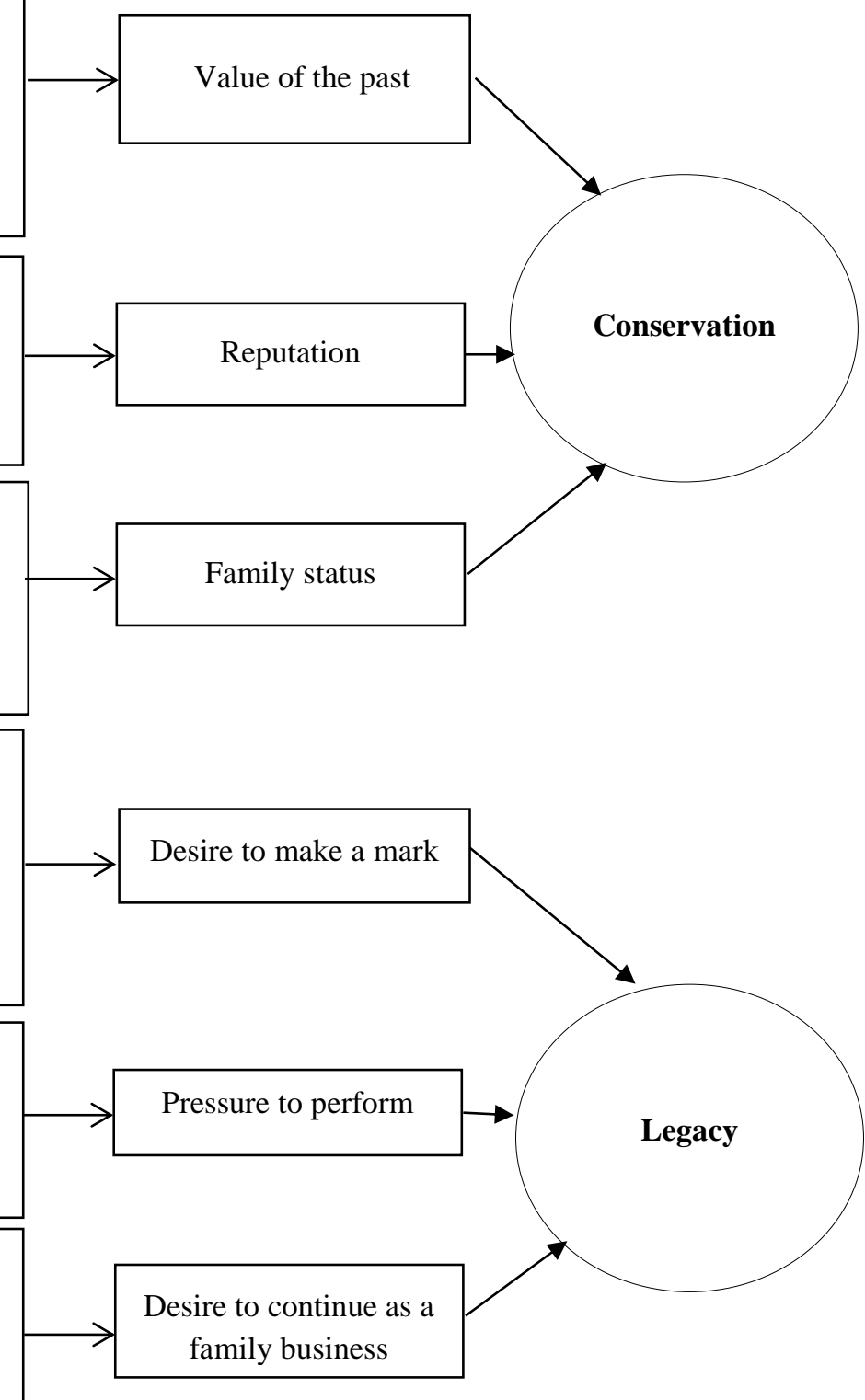
Table 2. Examples from the Data for Conserving Firms

\begin{tabular}{|c|c|c|}
\hline Case & Conserving (importance of the past) & Innovation \\
\hline Case C & 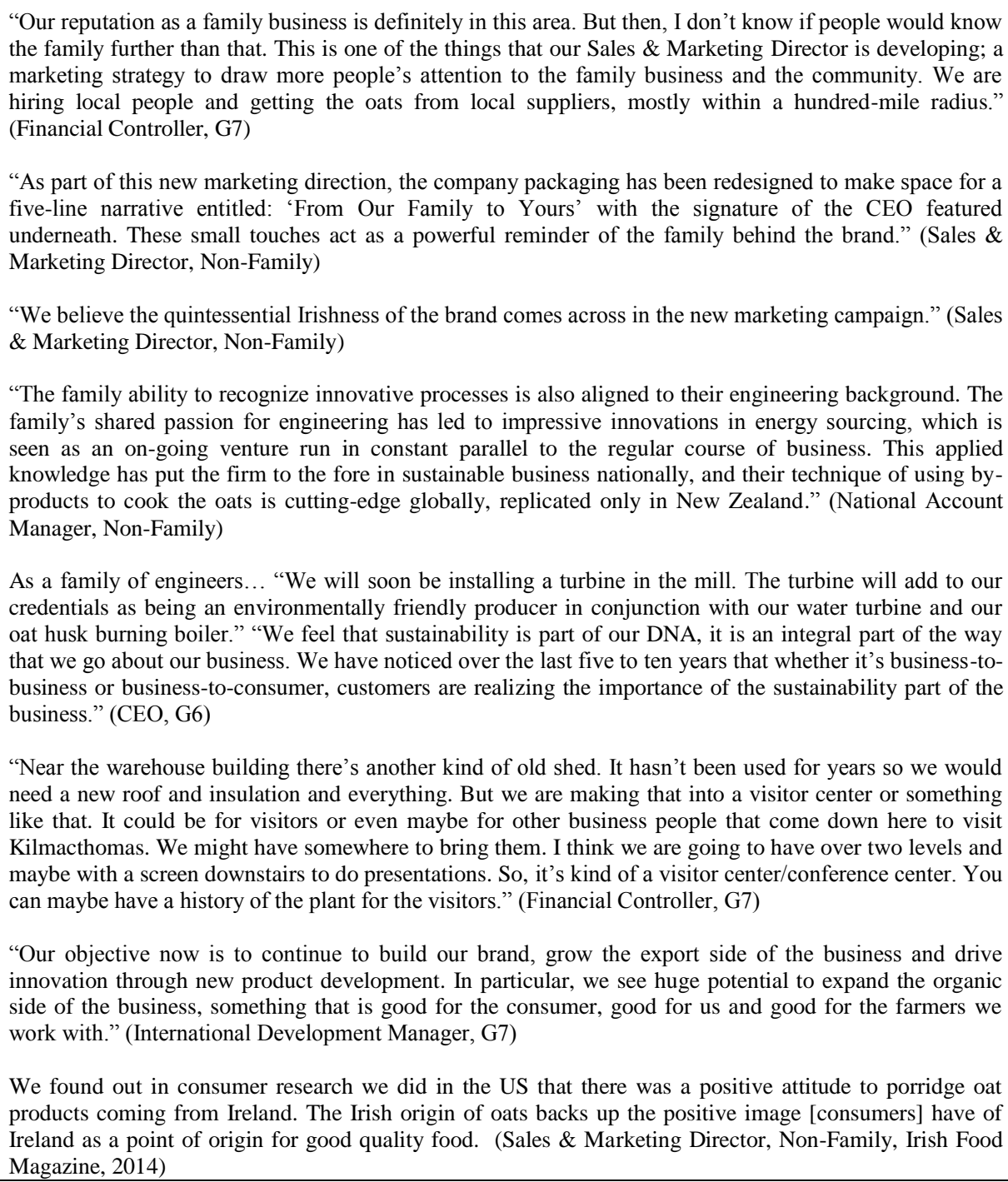 & $\begin{array}{l}\text { Marketing } \\
\text { Marketing }\end{array}$ \\
\hline
\end{tabular}

Table 3. Examples from the Data for Persisting Firms

\begin{tabular}{|c|c|c|}
\hline Case & Persisting (importance of long-term rewards) & Innovation \\
\hline Case B & $\begin{array}{l}\text { "We were using mostly monopumps and then we started using centrifugal pumps and that changed the } \\
\text { scene. We were buying from different places and, in 1974, he (co-founder) went to Italy. We were buying } \\
\text { domestic pumps then from another company in Dublin. But we said: if they are bringing in pumps from } \\
\text { Italy, why can't we do the same?" (Co-founder, G1) } \\
\text { "One of our strategies is to grow and acquire companies in the business areas where there is more money to } \\
\text { be made. If you look at the mix of revenues and margins that is changing, every year it's changing. We have } \\
\text { a } 2020 \text { plan which is to get somewhere between } 120 \text { and } 150 \text { million, and } 5 \% \text { net profit. And that's before } \\
\text { we do any acquisitions or half of that." (Deputy MD, G2) } \\
\text { "Predominantly, my own mission with them [partnership] is to become number one in the UK and Irish } \\
\text { markets for water treatment. We are going to start buying out a few of the smaller companies over the next } \\
\text { five years, which is something I would do because their R\&D function is big and strong enough to sustain a } \\
\text { conglomerated business." (Deputy MD, G2) } \\
\text { "Our partnership will ensure that we will develop and provide innovation and leadership for the industry." } \\
\text { (Deputy MD, G2) } \\
\text { "The plan from now to six years' time is to have new products coming out that we can license for all of the } \\
\text { UK and Ireland. We're installing new rota mold plastic tank manufacturing equipment that they [the } \\
\text { Canadian company] design and manufacture." (Deputy MD, G2) }\end{array}$ & $\begin{array}{l}\text { Acquisition } \\
\text { Partnership } \\
\text { Technology }\end{array}$ \\
\hline
\end{tabular}




\begin{tabular}{|c|c|c|}
\hline & $\begin{array}{l}\text { "What's required now all around Ireland is to upgrade your septic tanks. There are about } 500,000 \text { houses to } \\
\text { be upgraded in Ireland. Every one of them is going to need a slightly different solution. We are coming up } \\
\text { with different types of products for different options and applications i.e., you can have one of these, and } \\
\text { two of those, or you can have this and this together for this application." (Commercial Director, G2) } \\
\text { "We're actually putting in a new ERP (Enterprise Resource Planning) system. We are all working very hard } \\
\text { at the moment as we're going live in April.... A new process ERP system will decrease variable cost } \\
\text { components in manufacturing processes, techniques, machinery and software." (Operations Manager, non- } \\
\text { family) } \\
\text { This endorsement [SEAI] is further recognition of our ongoing efforts to develop cleaner technologies and } \\
\text { solutions, which reduce energy consumption and increase efficiency. Our vision is to become the most } \\
\text { sustainable company in the industry, providing energy efficient and innovative cost-saving water solutions } \\
\text { globally. (Company Report, 2016) } \\
\text { "Since 2008, we have become very active in the UK market both in the water utility sector and through our } \\
\text { acquisition of the UK company on environmental solutions. Combined, these new growth areas are } \\
\text { providing an important platform for the future growth and sustainability of the business. Significant } \\
\text { progress continues to be made in a number of key areas including R\&D, our Environmental, Health and } \\
\text { Safety and Quality Management Systems, as well as our energy and carbon reducing initiative." (MD, G1) }\end{array}$ & $\begin{array}{l}\text { Technology } \\
\text { Technology }\end{array}$ \\
\hline Case D & 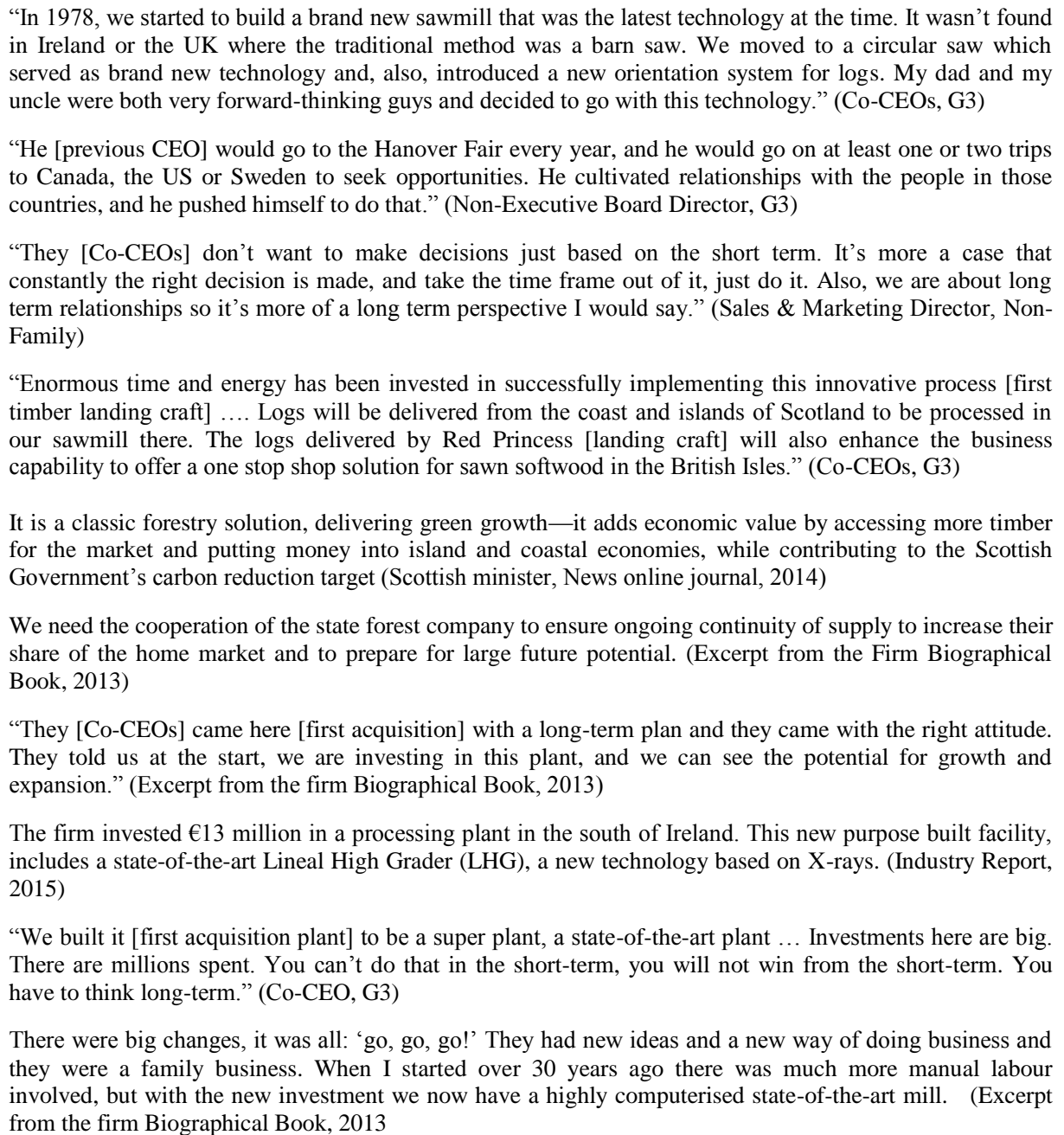 & $\begin{array}{l}\text { Process } \\
\text { Process } \\
\text { Process } \\
\text { Acquisition } \\
\text { Technology } \\
\text { Acquisition }\end{array}$ \\
\hline
\end{tabular}


Table 4. Examples from the Data for Legacy-Building Firms

\begin{tabular}{|c|c|c|}
\hline Case & Legacy-Building (importance of a long-lasting legacy) & Innovation \\
\hline Case A & $\begin{array}{l}\text { "So what we've done is we've diversified the family interests but not the tea business interests. We have } \\
\text { renewed the organizational structure and we have created an investment company... we're investing to } \\
\text { truly diversify the family business. So what we tried to do is to have two separate businesses, the tea } \\
\text { business and another business which is the vehicle for investing, so innovation in terms of organizational } \\
\text { structure." (Managing Director, G4) } \\
\text { "We took the decision to diversify } 15 \text { years ago. We have a tea business, which is profitable but may not } \\
\text { always be, who knows what problems could arise? It is a way to diversify risk and family interests, not tea } \\
\text { interest." (Managing Director, G4) } \\
\text { "They make investments in non-core activities through an investment vehicle. The investment vehicle is } \\
\text { funded by the tea company but the tea company wouldn't take any debt risks. And it is ring fenced in } \\
\text { terms of any debt that might be here which there isn't invariably. They make cash investments and they } \\
\text { wouldn't come back to the tea company." (Non-Executive Board Director, G4) } \\
\text { "From a family point of view there is a specific strategy which is growing wealth. In the future, this is not } \\
\text { going to come from the tea business; it's going to come from the investments. So as a family that made a } \\
\text { lot of money in tea, now we are diversified into shipbuilding, recruitment, media, TV, radio-all unrelated } \\
\text { businesses to the tea business." (Finance Director, Non-Family) } \\
\text { "The new investment strategy is a question of credibility investment portfolio. We want to keep the tea } \\
\text { business and pass it on, in better shape, to the next generation." (Finance Director, Non-Family) }\end{array}$ & $\begin{array}{l}\text { Business } \\
\text { Structure } \\
\text { Business } \\
\text { Structure } \\
\\
\text { Business } \\
\text { Structure } \\
\text { Business } \\
\text { Structure }\end{array}$ \\
\hline Case E & $\begin{array}{l}\text { "He [CEO] has this concept called "LINC," which is a family shareholding group. He has been trying to } \\
\text { put it in place for the last couple of years. It is about a collective governance structure." (Auditor, Non- } \\
\text { Family) } \\
\text { "Well, I suppose the whole family is a family business, but there is also the shareholding group of the } \\
\text { family. So my brothers are looking after two separate entities outside the firm but they are part of the } \\
\text { family group. We are trying to consolidate within the firm and create more cost effective business, and a } \\
\text { steadier business going forward." (General Manager, G2) } \\
\text { "What I'm trying to do or we're trying to do is a corporate restructuring ... we're going to have a quasi- } \\
\text { group structure whereby the new family shareholding group is going to be shared equally by the children." } \\
\text { (CEO, G1). } \\
\text { "[Because] I'm not going to live forever. I'm not, and I certainly ain't going to. What I want to do actually } \\
\text { is-genuine basis is I want to leave my legacy." (CEO, G1). } \\
\text { "We started with some professional advisors to get the mindset right for everybody in this new business } \\
\text { structure process." (CEO, G1). }\end{array}$ & $\begin{array}{l}\text { Business } \\
\text { Structure } \\
\text { Business } \\
\text { Structure } \\
\\
\text { Business } \\
\text { Structure } \\
\\
\text { Business } \\
\text { Structure }\end{array}$ \\
\hline
\end{tabular}

Figure 2. Innovation Patterns Framework for Multi-Generational Family Firms

LTO

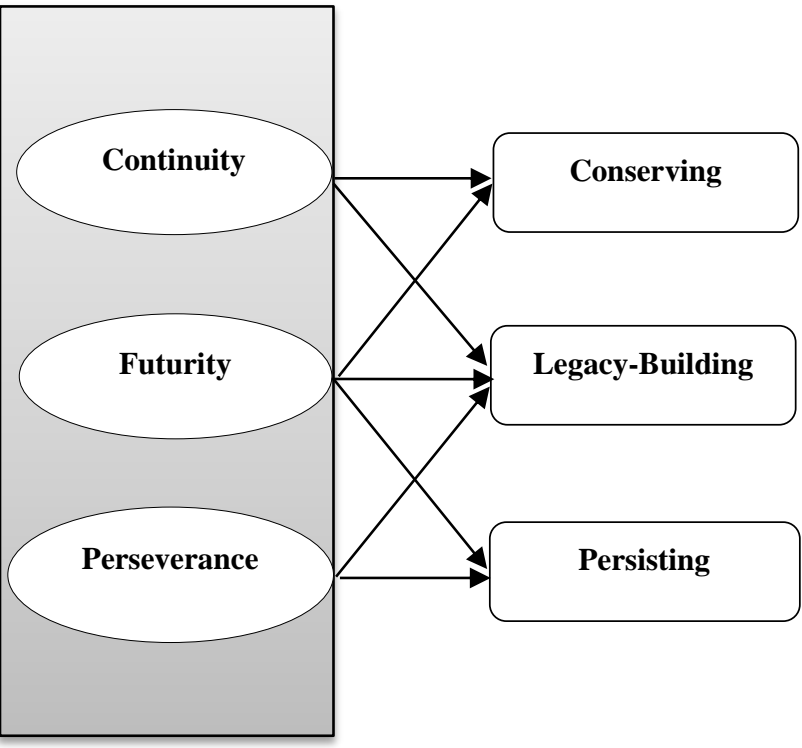

Innovation Outcomes

New Product/ Service

New Marketing

New Business Structure

New Process/ Technology

New M\&A 


\section{Appendix. Description of STEP Firms from Alternative Dataset}

\begin{tabular}{|c|c|c|c|c|c|c|c|c|c|}
\hline Case & Country & $\begin{array}{l}\text { Primary } \\
\text { Industry }\end{array}$ & $\begin{array}{c}\text { No. of } \\
\text { Employees }\end{array}$ & $\begin{array}{c}\text { Year } \\
\text { Founded }\end{array}$ & Generation & $\begin{array}{c}\text { Family } \\
\text { CEO }\end{array}$ & $\begin{array}{c}\text { Family } \\
\text { Ownership }\end{array}$ & $\begin{array}{c}\text { Innovation } \\
\text { Motive }\end{array}$ & $\begin{array}{l}\text { Innovation } \\
\text { Outcome }\end{array}$ \\
\hline 1 & Australia & Diverse & 600 & 1948 & $3^{\text {rd }}$ & Yes & $100 \%$ & Persisting & Processes \\
\hline 2 & Australia & $\begin{array}{c}\text { Transportation } \\
\text { \& Tourism }\end{array}$ & 135 & 1921 & $5^{\text {th }}$ & Yes & 100 & Persisting & Technologies \\
\hline 3 & Belgium & Lingerie & 1550 & 1919 & $3^{\text {rd }}$ & Yes & 59 & Conserving & $\begin{array}{l}\text { Products } \\
\text { Marketing }\end{array}$ \\
\hline 4 & Belgium & $\begin{array}{l}\text { Reduction of } \\
\text { waste } \\
\text { combustion } \\
\text { biomass and } \\
\text { green energy }\end{array}$ & 310 & 1912 & $4^{\text {th }}$ & Yes & 100 & Persisting & Technologies \\
\hline 5 & Belgium & $\begin{array}{c}\text { Heat Exchangers } \\
\text { and Process } \\
\text { Equipment }\end{array}$ & 31 & 1921 & $3^{\text {rd }}$ & Yes & 100 & Persisting & Processes \\
\hline 6 & Finland & Advertising & 98 & 1988 & $2^{\text {nd }}$ & Yes & 89 & Persisting & Technologies \\
\hline 7 & Finland & Biotechnology & 370 & 1988 & $2^{\text {nd }}$ & No & 50 & Persisting & Processes \\
\hline 8 & Finland & $\begin{array}{l}\text { Heat-Retaining } \\
\text { Fireplaces }\end{array}$ & 500 & 1979 & $2^{\text {nd }}$ & Yes & Public & Persisting & Processes \\
\hline 9 & France & Taxi & 2195 & 1960 & $2^{\text {nd }}$ & Yes & 100 & Persisting & Technologies \\
\hline 10 & France & Furniture & 1200 & 1967 & $3^{\text {rd }}$ & Yes & 99 & $\begin{array}{l}\text { Legacy- } \\
\text { building }\end{array}$ & $\begin{array}{l}\text { Business } \\
\text { Structure }\end{array}$ \\
\hline 11 & France & $\begin{array}{l}\text { Pharmaceutical } \\
\text { for Animals }\end{array}$ & 2260 & 1968 & $2^{\text {nd }}$ & No & 64 & Conserving & Products \\
\hline 12 & Germany & Timber & 110 & 1953 & $2^{\text {nd }}$ & Yes & 100 & Persisting & Processes \\
\hline 13 & Italy & $\begin{array}{c}\text { Renewable } \\
\text { Energy }\end{array}$ & 144 & 1906 & $4^{\text {th }}$ & No & 100 & $\begin{array}{l}\text { Legacy- } \\
\text { building }\end{array}$ & $\begin{array}{l}\text { Business } \\
\text { Structure }\end{array}$ \\
\hline 14 & Italy & $\begin{array}{c}\text { Food } \\
\text { manufacturing \& } \\
\text { retail }\end{array}$ & 97 & 1932 & $3^{\text {rd }}$ & Yes & 100 & Persisting & Processes \\
\hline 15 & Italy & $\begin{array}{c}\text { Pharmaceutical } \\
\text { \& Healthcare }\end{array}$ & 351 & 1932 & $3^{\text {rd }}$ & Yes & 100 & Persisting & Acquisition \\
\hline 16 & Italy & Molding & 190 & 1976 & 2 & Yes & 100 & Persisting & Acquisition \\
\hline 17 & Switzerland & $\begin{array}{c}\text { Cancer } \\
\text { healthcare }\end{array}$ & 600 & 1976 & $3^{\text {rd }}$ & Yes & 100 & Persisting & Technologies \\
\hline 18 & Switzerland & Wine production & 34 & 1944 & $3^{\text {rd }}$ & Yes & 100 & Conserving & Marketing \\
\hline 19 & Switzerland & $\begin{array}{c}\text { Food } \\
\text { (Chocolate) }\end{array}$ & 175 & 1926 & $3^{\text {rd }}$ & Yes & 100 & Conserving & $\begin{array}{c}\text { Products } \\
\text { Marketing }\end{array}$ \\
\hline 20 & Switzerland & Textile & 2000 & 1830 & $7^{\text {th }}$ & Yes & 100 & Persisting & Processes \\
\hline 21 & Switzerland & Pharmaceutical & 340 & 1867 & $5^{\text {th }}$ & Yes & 100 & Conserving & Marketing \\
\hline 22 & Switzerland & Freight & 110 & 1900 & $3^{\text {rd }}$ & Yes & 100 & Persisting & Processes \\
\hline 23 & Turkey & $\begin{array}{c}\text { Auto-parts } \\
\text { Manufacturing }\end{array}$ & 1400 & 1968 & $2^{\text {nd }}$ & No & 100 & Conserving & Services \\
\hline 24 & Turkey & Education & 240 & 1980 & $2^{\text {nd }}$ & Yes & 100 & Persisting & Processes \\
\hline 25 & UK & $\begin{array}{c}\text { Hotel } \\
\text { management }\end{array}$ & 200 & 1769 & $8^{\text {th }}$ & Yes & 100 & $\begin{array}{l}\text { Legacy- } \\
\text { building }\end{array}$ & $\begin{array}{l}\text { Business } \\
\text { Structure }\end{array}$ \\
\hline 26 & USA & $\begin{array}{l}\text { Automotive } \\
\text { information }\end{array}$ & 500 & 1988 & $2^{\text {nd }}$ & Yes & 66.6 & Persisting & Acquisition \\
\hline 27 & USA & $\begin{array}{l}\text { Manufacturer } \\
\text { fasteners and } \\
\text { components for } \\
\text { auto }\end{array}$ & 574 & $\begin{array}{l}1982 \\
\text { (bought } \\
\text { by the } \\
\text { family) }\end{array}$ & $2^{\text {nd }}$ & Yes & 100 & $\begin{array}{l}\text { Legacy- } \\
\text { building }\end{array}$ & $\begin{array}{l}\text { Business } \\
\text { Structure }\end{array}$ \\
\hline
\end{tabular}

